\title{
Bargaining Power and Outside Options in the Interbank Lending Market
}

\author{
Puriya Abbassi, Falk Bräuning, and Niels Schulze
}

\begin{abstract}
:
We study the role of bargaining power and outside options with respect to the pricing of overthe-counter interbank loans using a bilateral Nash bargaining model, and we test the model predictions with detailed transaction-level data from the euro-area interbank market. We find that lender banks with greater bargaining power over their borrowers charge higher interest rates, while the lack of alternative investment opportunities for lenders lowers bilateral interest rates. Moreover, we find that when lenders that are not eligible to earn interest on excess reserves (IOER) lend funds to borrowers with access to the IOER facility, they do so at rates that are below the IOER rate; in turn, these borrowers put the funds in their reserve accounts to earn the spread. Our findings highlight that this persistent arbitrage opportunity is not merely a result of the lack of alternative outside options for some lenders, but rather it crucially depends on lenders' limited bilateral bargaining power, leading to a persistent segmentation of prices in the euroarea interbank market. We examine the implications of these findings for the transmission of euro-area monetary policy.
\end{abstract}

JEL Classifications: E4, E58, G21

Keywords: bargaining power, over-the-counter market, monetary policy, money market segmentation

Puriya Abbassi and Niels Schulze are principal financial stability experts at the Deutsche Bundesbank; their emails are puriya.abbassi@bundesbank.de and niels.schulze@bundesbank.de. Falk Bräuning is a senior economist in the research department of the Federal Reserve Bank of Boston; his email is falk.braeuning@bos.frb.org.

The authors thank Klaus Adam, Morton L. Bech, Martin Diehl, Darrell Duffie, Jens Eisenschmidt, Falko Fecht, Craig Furfine, Co-Pierre Georg, Carsten Hartkopf, Matti Hellqvist, Robert King, Antoine Martin, Christoph Memmel, Alexander Müller, Joe Peek, Stefan Rosenthal, and Sascha Steffen for valuable comments and suggestions. They are indebted to the journal editor and anonymous referee for their excellent contributions. Puriya Abbassi and Niels Schulze are members of a user group with access to TARGET2 data in accordance with Article 1(2) of Decision ECB/2010/9 of July 29, 2010, on access to and use of certain TARGET2 data. The Deutsche Bundesbank and the PSSC have checked the paper against the rules for guaranteeing the confidentiality of transaction-level data imposed by the PSSC pursuant to Article 1(4) of the issue mentioned above. This paper presents preliminary analysis and results intended to stimulate discussion and critical comment. The views expressed herein are those of the authors and do not indicate concurrence by the institutions to which the authors are affiliated, including the Federal Reserve Bank of Boston or the Federal Reserve System. This paper, which may be revised, is available on the website of the Federal Reserve Bank of Boston at https://www.bostonfed.org/publications/research-department-working-paper.aspx.

This version: June 2020

https://doi.org/10.29412/res.wp.2020.10 


\section{INTRODUCTION}

In most financial systems, only selected financial institutions (banks hereafter) can hold and trade central bank reserves. The interest rate that banks charge to borrowers of these reserves in the over-the-counter (OTC) interbank market plays an important role not only for liquidity reallocation and risk sharing in the banking sector, but also for the pricing of other financial assets, and thus the functioning of the financial system as a whole. As a result, the effect of any (conventional or unconventional) monetary policy depends on the rates at which reserve balances are traded and thus transmitted to the wider economy. Indeed, major central banks implement their (conventional) monetary policy by steering an average effective level of the shortest interbank rate (that is, the overnight interbank rate) around a defined target rate.

In this paper, we ask how reliable an average effective overnight interbank rate is for the implementation of monetary policy. This question has re-emerged in the context of the large supply of central bank reserves in the aftermath of the Lehman failure that has exerted substantial downward pressure on the average effective overnight interbank rate, the key target rate of the central banks in the United States, the United Kingdom, and the euro area. ${ }^{2}$ In the United States, the volume-weighted median overnight interest rate - the effective federal funds rateeven decreased persistently after 2009 to levels below the interest rate that the Federal Reserve pays on reserves (the interest rate on excess reserves, or IOER rate), which had been commonly understood to provide a floor for the interbank interest rate (for example, Goodfriend 2002; Friedman and Kuttner 2011). As a consequence, concerns have been raised about the efficiency of liquidity reallocation in the banking sector and, thus, the efficacy of monetary policy transmission in general (for example, Keister, Martin, and McAndrews 2008).

It has been argued that this puzzling outcome for the US federal funds rate is related to some participants in the market for reserves, such as government-sponsored enterprises (GSEs), not being eligible to earn interest on their reserve balances, thereby limiting their outside investment options (for example, Bech and Klee 2011). As a result, these institutions are willing to lend funds below the IOER rate, which persistently drives the effective federal funds rate below the IOER rate. We show that this pattern is not specific to the United States. Indeed, we find that even in the euro area, where the effective overnight interest rate - the Eonia rate - is

\footnotetext{
${ }^{1}$ While central banks typically target the average overnight rate, the variation in overnight interest rates is commonly curtailed by a "corridor" of policy interest rates, that is, one that is paid on reserve balances held at the central bank (IOER rate) and another that is charged when banks borrow balances from the central bank (lender of last resort, or LOLR, rate) directly.

2 The role of the average effective overnight rate has also been discussed by, for example, Keister, Martin, and McAndrews (2008) and Bindseil and Jablecki (2011). Bindseil (2004) and Whitesell (2006a, 2006b) raise similar questions while discussing the different frameworks of monetary policy implementation before the financial crisis. More recently, a similar discussion has emerged regarding the information content of the London interbank offered rate (LIBOR).
} 
higher than the Eurosystem's IOER rate, a substantial share of overnight interbank loans (22 percent of all euro-denominated overnight loans) trades below the IOER rate during periods of a positive IOER rate. As in the United States, these trades are conducted by lenders that have no access to the Eurosystem's IOER facility, that is, lenders that cannot deposit reserve balances in an interest-bearing account.

We argue that this persistent anomaly of trading below the IOER rate reflects a deeper structural issue in the interbank market for central bank reserves. Based on a simple bilateral Nash bargaining model, we show that the price for a bilateral interbank credit is determined by the bilateral bargaining power and the alternative investment opportunities of both the lender and the borrower in a given trade. Indeed, we argue that different access policies (for example, being eligible or ineligible to earn the IOER rate) are not a sufficient condition for the interbank market to become segmented, but that persistent bilateral bargaining power in the OTC interbank market is crucial for interest rates to diverge among market participants and settle even below the IOER rate. More generally, we show that differences in bilateral bargaining power across institutions can lead to substantial and persistent dispersion of overnight interest rates among market participants, even when they have similar outside investment options.

To empirically test these predictions of our model, we rely on detailed transaction-level data on euro-denominated overnight interbank loans derived from the Eurosystem's payment and settlement system, TARGET2. Our data set contains information on borrowers and lenders of overnight interbank loans, as well as the interest rates they negotiate, which are necessary to test the effects of bilateral bargaining power that can be estimated only by using loan-level data. ${ }^{3}$ We match this database with proprietary bank-level data on each bank's actual recourse to the IOER facility, that is, the excess reserves each bank holds at the Eurosystem's facility to earn the IOER rate. We complement these data further with day-level information, notably lender of last resort (LOLR) funding, the amount outstanding associated with open market operations, and a market liquidity indicator for the euro-area money market and for the foreign exchange, bond, and equity markets. The detailed loan-level information allows us to examine the role of bilateral bargaining power and outside options on interbank loan rates at the bankpair level; it also allows us to investigate the factors driving the heterogeneity in both variables.

\footnotetext{
${ }^{3}$ In contrast to the US Fedwire data, TARGET2 provides information on the ultimate borrower and the ultimate lender, as well as information on settling sending and settling receiving institutions. This distinction is crucial for the identification of unique matches, which otherwise could bear the substantial problem of false positives, as explained in Armantier and Copeland (2012) and the Research Group of the Federal Reserve Bank of New York. For our study, this data set is crucial, as it allows us to identify the bargaining power and outside options of the actual borrower and lender involved in a given trade.
} 
We use the granularity of our data to compute several measures of bargaining power for each trader, depending on the bank's lending and borrowing concentration, respectively, in the OTC interbank lending market (for example, the Herfindahl-Hirschman index [HHI]). To measure the outside investment options of each lending institution, we exploit a distinct feature of our data set: 29 percent of the total overnight euro interbank credit volume is provided by noneuro-area lender banks. While these banks account for 22 percent of all loans in the euro interbank market and thus play an economically meaningful role in the allocation of euro-denominated central bank reserves, they do not have direct access to the Eurosystem's facilities, including open market operations, the discount window, and the IOER facility. Therefore, these banks are limited in their alternatives to manage end-of-day excess balances, for example, by placing excess end-of-day reserves at the IOER facility to earn the IOER rate. ${ }^{4} \mathrm{We}$ will use this distinct difference across lending institutions to account for different outside options among lending institutions.

In line with our model's predictions, we find the following robust main results: (1) lenders with greater bargaining power over their borrowers are able to negotiate higher interest rates; (2) lenders with outside options (that is, access to the Eurosystem's IOER facility) charge higher interest rates (about 10 basis points higher on average) for overnight loans compared with lenders without access to the IOER facility; (3) the negotiated interest rates are more sensitive to the bargaining power of the lender bank if that institution has no outside investment options; and (4) the bilateral interest rates can fall below the euro area's IOER rate if the bargaining power of the lender is sufficiently weak. Our results are economically meaningful. For instance, we find that during a period of a positive IOER rate, the differential between the interest rates of lenders with and lenders without outside investment options is consistently positive and amounts to as much as 50 basis points; on average, lenders with no access to the IOER facility (no outside options) negotiate an interest rate for overnight loans that is about 10.3 basis points lower than the interest rate their peers negotiate. ${ }^{5}$ This suggests a substantial fragmentation of the euro-area interbank money market in terms of prices. Moreover, we find that about 33.4 percent of all overnight loans in our data set settle at an interest rate below the interest rate paid on excess reserves. At the same time, we find that the borrowing counterparties of these

\footnotetext{
${ }^{4}$ As we will discuss in Section 2, we use an institution-to-parent SWIFT BIC code-matching table that links each institution to its ultimate parent institution at the highest consolidated level. This ensures that we can relate each institution to its ultimate parent bank to determine whether it has policy access to the Eurosystem's facilities, including the IOER facility. That is, we account for the fact that banks that have no direct policy access themselves might have indirect policy access through their euro-based affiliates (subsidiaries and branches).

5 The below-IOER-rate trades disappeared when the Eurosystem set the IOER rate to zero in July 2012 and thus removed the difference between the outside options for euro-area lenders and those for non-euro-area lenders. Note, however, that these differences in outside options simply bring to the surface the deeper structural impact of the heterogeneity in bilateral bargaining power that induces the observed persistent price segmentation.
} 
below-IOER trades deposit more than 36 euro cents of each euro borrowed at the Eurosystem's IOER facility to fetch the higher IOER rate, thereby making an arbitrage spread. We find that this arbitrage opportunity is persistent due to the significant bargaining power of these borrowers over lenders that lack outside options. This implies that the IOER rate is not necessarily a strict floor for interest rates in the euro interbank market and that it can promote arbitrage trades below the IOER rate.

To understand the variation of bargaining power as a key driver of the interbank market segmentation in more detail, we take a further step and use our model to examine the bank-pair, bank, and time dimensions of bargaining power. We find that bargaining power exhibits an important heterogeneity at the bank-pair level (21 percent of the variation) that cannot be explained by a common time variation and, hence, cannot be studied using aggregate interbank lending data. Our results show that banks with a high lending or borrowing concentration (that is, a lack of diversification) are less able to negotiate favorable interest rates. However, we find important heterogeneity that depends on the outside options of lenders. In particular, for lender banks without access to the IOER facility, having a well-diversified lending network strengthens their bargaining power vis-à-vis borrower banks that have access policy.

In light of these findings, we further study the implications for monetary policy. In our setup, monetary policy affects interbank lending rates through two main channels. First, changes in the interest rate corridor for overnight depositing and lending reserves affect the value of the outside options to interbank lending, as well as the outside option differential between the banks with access to IOER and those without it. Second, monetary policy affects the bilateral bargaining power of participants in the interbank market. Specifically, a smaller amount of liquidity provided to the banking system shifts bargaining power to the lending banks. For instance, we find that the Eurosystem's switch from the variable-rate tender to the fixed-rate, full-allotment policy in 2008 significantly strengthened the bargaining power of borrower banks. This finding has particular implications for any potential departure from the current low-interest-rate policy. The extent to which increases in the Eurosystem's policy rates will be transmitted to interbank rates depends crucially on the participation of lenders that lack access to IOER and the distribution of bargaining power in the interbank market. Indeed, our analysis shows that a substantial participation of banks without access to the IOER facility will assert downward pressure on interbank rates when the IOER rate moves back into positive territory (and, hence, different access policies across institutions matters). On the other hand, a large reduction of excess reserves (or a potential return to a variable-rate tender procedure) will shift bilateral bargaining power away from borrowers and toward lender banks and increase 
interbank rates. More generally, the corollary of these findings is that monetary policy needs to rely on transaction-level information rather than average effective overnight interest rates in order to (1) assess frictions in interbank markets, (2) estimate its strength in affecting broader financial markets, and (3) evaluate the potential outcomes of (conventional and unconventional) policy measures during both normal and crisis times.

\section{Contribution to the Literature}

Our findings relate to several strands of the literature. First, our study adds to the literature on monetary policy implementation and its transmission through the interbank market (Whitsell 2006a and 2006b; Berentsen and Monnet 2008; Bech and Klee 2011; Kraenzlin and Nellen 2015). In particular, Kraenzlin and Nellen (2015) show that for the Swiss market, the lack of access to IOER induces money market segmentation with significant repercussions for monetary policy and financial stability. Bech and Klee (2011), among others, argue that in the United States, because government-sponsored enterprises (GSEs) are not eligible to earn interest on reserves, arbitrage opportunities arise and induce money market segmentation in the federal funds market. While both of these studies emphasize the role of access to IOER (or the lack of access) for both monetary policy and financial stability, our results add another important dimension: We highlight that both the lack of access to central bank facilities and especially bilateral bargaining power are necessary for such arbitrage opportunities to be persistent and for money markets to become segmented (in line with Furfine 2011). As we show, our results have important implications for the conduct of monetary policy and the transmission of its stance to the wider economy.

Second, our paper contributes to the literature on trading in OTC markets. Duffie, Garleanu, and Pedersen (2005) establish bargaining power as a key determinant for OTC trades. Zhu (2012) proposes a dynamic model that introduces outside options, in addition to bargaining power, to study the pricing in OTC markets. While these papers study the role of bargaining power and outside options for OTC markets in general, other theoretical contributions focus on specific segments, such as the government bond market (Vayanos and Weill 2008), credit default swap markets (Atkeson, Eisfeld, and Weill 2015), and the federal funds market (Afonso and Lagos 2015a and 2015b). In this paper, we argue that in a frictionless world where borrower banks engage in Cournot-type competition, borrower bargaining positions, and thus segmentation aspects in OTC markets would fade away as every lender provides the asset at an interest rate that equals the outside option of the borrowing banks, irrespective of the lender's outside 
options. Therefore, persistent price differentials between agents with outside options and those without can only be a result of the existence of both different outside investment options and bilateral bargaining power of borrowing institutions. In line with this rationale, we provide empirical evidence for the role of bilateral bargaining power and outside options for the pricing of OTC-traded interbank loans.

Third, our work adds to the literature on liquidity reallocation in interbank lending markets. Afonso, Kovner, and Schoar (2011), Iyer and Peydró (2011), Acharya, Gromb, and Yorulmazer (2012), Acharya and Merrouche (2012), Abbassi et al. (2013), Iyer et al. (2014), and others study the allocation of funds among banks in response to liquidity shocks. Our findings suggest that even when a shock affects only a subset of banks, it is transmitted to the rest of the banking sector in ways that are shaped by both the bilateral bargaining power and outside options. This is in contrast to standard models with random spot transactions where, it is argued, supply shocks have symmetric effects on all banks in the market. In this regard, our paper is also related to the literature that studies the OTC structure of the interbank market using network theory. In particular, several recent papers document a core-periphery structure of the interbank networks in which a few banks trade with many counterparties while the majority have only a few counterparties; see Bech and Atalay (2010), Craig and von Peter (2010), Fricke and Lux (2012), Iori et al. (2008), Langfield, Liu, and Ota (2014), Lelyveld and Veld (2012), and Rordam and Bech (2009). Consistent with these studies' findings of sparse interbank networks, we find that stronger portfolio concentration affects a bank's bilateral bargaining power and thus the terms of an interbank loan.

Finally, our paper relates to the literature that studies the role of lending relationships in the interbank market. Furfine (1999) was the first to study the role of relationship formation in interbank lending markets, especially for smaller institutions, in alleviating the problem of asymmetric information. Furfine (2001) also shows that a bank can pursue relationships with other banks to signal its good-credit-risk profile. Cocco, Gomes, and Martins (2009), Afonso, Kovner, and Schoar (2013), and Bräuning and Fecht (2017) show that banks rely on repeated interactions with counterparties. Our paper shows that bargaining power and outside options play an economically meaningful role beyond the one involving relationship lending, irrespective of the size of the banks. In this regard, our paper is closely related to the emerging strand of literature that studies the role of bilateral bargaining power in decentralized interbank markets (for example, Allen and Babus 2009; Abreu and Manea 2012; Blasques, Bräuning, and van Lelyveld 2015; and Bech and Monnet 2016). 
The remainder of the paper is structured as follows. Section 2 describes our data set and the euro money market. Section 3 introduces the bargaining model, derives testable predictions, and validates them empirically. Section 4 analyzes the determinants of bilateral bargaining power and discusses the monetary policy implications. Section 5 concludes.

\section{THE EURO INTERBANK MARKET AND DATA}

In the euro-area interbank lending market, all euro-denominated transactions are executed with an electronic request made by a financial institution to the Eurosystem via its payment and settlement system, TARGET2. Such a request debits the euro reserve balance account of the initiating financial institution by a stipulated amount in favor of another financial institution. All financial institutions with a banking license in the euro area have such access to TARGET2, which they use for settling their euro payments. Financial institutions from some European countries that are not part of the euro area, such as Switzerland and the United Kingdom, are also granted TARGET2 access to facilitate euro transactions with other European banks. ${ }^{6}$ A bank, however, needs an account with a euro-area bank (or any of its branches or subsidiaries headquartered in the European Union) in order to send (or receive) euro-denominated payments. In these cases, the euro-area house bank (correspondent bank) will act as an intermediary institution and settle the transaction.

Banks have no incentives to hold reserve balances in excess of mandatory requirements at the close of the business day, because these excess reserves held in this euro reserve balance account do not earn interest given the framework of the Eurosystem. However, in our sample period, euro-area banks (EA banks henceforth) can, and generally do, transfer end-of-day balances in excess of mandatory requirements from their euro reserve balance account to their IOER facility (deposit facility) accounts held with the Eurosystem, where these excess reserves are remunerated with the prevailing IOER rate. On the other hand, other banks, including banks from European countries that are not part of the euro area (non-EA banks henceforth), do not have such an access policy to the Eurosystem's IOER facility; excess reserves remain in their TARGET2 accounts and bear no interest rate. ${ }^{7}$ That is, these banks have the incentive to exchange their end-of-day balances for interest-bearing overnight assets as long as the interest rate is greater than the shadow cost of leaving the reserves at their accounts, which is 0 percent.

\footnotetext{
${ }^{6}$ More precisely, banks from countries that are part of the European Economic Area (that is, European Union countries as well as Switzerland, Norway, Lichtenstein, and Iceland) are eligible to access TARGET2 directly.

${ }^{7}$ With the introduction of negative interest rates paid on excess reserves in mid-2014, this institutional design was changed. Since June 11, 2014, any bank that has positive balances in its TARGET2 account is charged with the prevailing IOER rate.
} 
We will use this distinct feature of the Eurosystem's access policy to identify differences between EA and non-EA banks with regard to outside options.

Our empirical analysis is based on transaction-level data on overnight interbank money market loans from TARGET2 for the period of June 2008 through June 2012. ${ }^{8}$ These data allow us to identify the ultimate borrower bank and the ultimate lender bank, ${ }^{9}$ the amount lent, and the interest rate. ${ }^{10}$ Having access to loan-level data is crucial to study the effects of bargaining power and outside options that depend on the specific borrower and lender of a given loan. We supplement these transaction-level data on overnight interbank loans with proprietary banklevel data on individual banks' daily recourses to the Eurosystem's IOER facility, specifically, the account in which excess reserves are remunerated and can be deposited overnight. That is, for each EA bank, we observe the value of end-of-day balances that it transfers to its account held with the Eurosystem to earn the IOER rate. In addition, we obtain daily data on the total amount outstanding associated with the Eurosystem's open market operations, the total value of excess reserves held by all banks at the IOER facility, the IOER rate, a money market liquidity indicator, and a liquidity measure for the foreign exchange, bond, and equity market in the euro area, all of which are provided by the Eurosystem's Statistical Data Warehouse.

Our raw data set comprises 1,559 borrowers and 2,116 lenders. We account for the different bank branches by consolidating banks on the first eight digits of their respective SWIFT BIC code (from the initial 11 digits). Moreover, we use a parent-institution SWIFT BIC code matching table that links each (subsidiary) institution to its ultimate parent institution at the highest consolidation level. This procedure ensures that we can relate each institution to its ultimate parent institution to determine whether it has access to the Eurosystem's facilities, including the IOER facility, which will be our measure for a bank's outside options. Moreover, we prune our data set as follows. We restrict our analysis to transactions carried out across

\footnotetext{
${ }^{8}$ The start of our sample corresponds to the official launch of TARGET2; we chose the ending date to ensure that our results are not driven by the Governing Council's decision to set the IOER rate to zero as of July 11,2012. Moreover, with the IOER facility rate set at zero, the opportunity cost of not transferring end-of-day excess balances to the IOER facility to earn the interest on excess reserves also falls to zero and thus reduces lenders' outside options. In Appendix Figure 1, we show that after the outside options of EA banks reach zero in response to the interest rate cut in mid-2012 and thus equal the outside options of non-EA lender banks, we do not observe any trades below the IOER rate. We leave the analysis of this period for future research. Note, however, that these differences in outside options simply bring to the surface the deeper structural impact of the heterogeneity in bilateral bargaining power that induces the persistent price segmentation, as we will discuss in Section III.1.

${ }^{9}$ In contrast to the US Fedwire data, TARGET2 provides information on the ultimate borrower and ultimate lender, as well as on the settling sender and settling receiver bank. The distinction is crucial for the identification of unique matches, which otherwise could bear the substantial problem of false positives, as explained in Armantier and Copeland (2012).

${ }^{10}$ The identification of each overnight interbank loan is based on a refined version of the Furfine (1999) algorithm as developed by Arciero et al. (2016). The algorithm-based estimation quality is checked against actual euro-area overnight loans from supervisory data sets (Bank of Spain) and from private data sets (Italy's e-MID). Arciero et al. (2016) and De Frutos et al. (2014) validate the TARGET2 interbank loan data using the Italian uncollateralized e-MID trading platform and the Spanish unsecured post-trading platform MID, respectively. The quality checks reveal that the TARGET2 interbank loan-level data match well with the actual Italian and Spanish unsecured money market data (incorrectly identifying less than 1 percent of payment legs as interbank loans), which also verifies the unsecured nature of the loans in our data. The quality of the interbank data for the United States and the United Kingdom is not easy to validate due to the lack of actual transaction-level data (Armantier and Copeland 2012).
} 
consolidated banking groups, as opposed to intra-banking-group transactions. ${ }^{11}$ We do so because the effective lending rate in the euro-area interbank market is governed primarily by transactions between banks of different banking groups. ${ }^{12}$ We also restrict our analysis to banks that trade with more than one counterparty on any given day, thereby reducing our sample to the most active banks in the market. (All results are, however, robust against the exclusion of these banks.) We also exclude non-EA borrowers from the analysis, restricting it to EA borrower banks, as they are counterparties to the Eurosystem and therefore crucial for the monetary transmission process in the euro area. Our identification thus relies on trades by non-EA lenders versus EA lenders to EA borrowers.

Our final sample consists of 376 EA borrowers and 919 (EA and non-EA) lenders accounting for 89 percent of the loans of the total overnight interbank market. Out of these 919 lenders, 549 are headquartered in countries where the euro is the official currency (EA lenders). The remaining 370 lenders are based in countries outside the euro area (non-EA lenders). ${ }^{13}$ Overall, more than 29 percent of the total overnight interbank credit volume (22.6 percent of all loans) is provided by non-EA lender banks, thereby rendering their role in the euro-area interbank lending market economically meaningful.

\section{Predictions from a Nash Bargaining Model}

In this section, we introduce a simple model that guides us in examining the role of bargaining power and different outside options with respect to the pricing of interbank loans in a decentralized over-the-counter (OTC) market. We then use our loan-level data to evaluate the model predictions.

\subsection{THE MODEL}

Our model's main intuition is that the price for a bilateral interbank credit is determined by the bargaining power and alternative investment opportunities of both the lender and the borrower in a given trade. In particular, if for a given trade, the lender bank has more bargaining power than the borrower does (or, equivalently, the borrower bank has less bargaining power

\footnotetext{
${ }^{11}$ That is, any loan between, say, Deutsche Bank (Germany) and Santander (Spain) will be reflected in our data set, while a loan between, say, Deutsche Bank (Germany) and Deutsche Bank (Spain) will not be included.

12 This is an outcome of the Eurosystem's operational framework that grants access to its open market operations to all banks that can provide eligible collateral. In the United States, the allocation of central bank reserves in monetary policy operations relies on a small set of predetermined primary dealers.

${ }^{13}$ Of these 370 non-EA lenders, 186 are based in European countries (including the United Kingdom, Switzerland, Norway, etc.), 138 banks are in Asian countries (including Western Asia) or Russia, 32 are in African countries (including Egypt), and 14 are headquartered in either North America or South America. Lenders from European countries that do not have the euro as their currency are the largest group of non-EA lender banks, accounting for about 63 percent of the total non-EA lending volume (58 percent of loans). Banks from Asian countries are the second-largest group, with about 37 percent of the total non-EA lending volume (31 percent of loans).
} 
than the lender does), the lender bank can fetch a higher interest rate on the loan. Moreover, if the lender bank has better outside investment options, everything else being equal, the lender will negotiate a higher rate to reduce the otherwise higher opportunity costs. As a consequence of bilateral bargaining power and the existence or lack of alternative investment options for some banks, the money market can become segmented with respect to the pricing of OTCtraded interbank loans; that is, some bank pairs will trade at substantially different prices compared with others.

Denote the set of euro area banks by $N^{E A}$ and the set of non-euro area banks by $N^{n o n-E A}$, and let $N=N^{E A} \cup N^{n o n-E A}$ represent the set of all banks. All banks within the euro area (EA banks hereafter) have full recourse to the Eurosystem's facilities, in particular, the standing facilities. That is, EA banks can borrow euro-denominated overnight funds from the marginal lending facility of the European Central Bank (ECB) at a penalty rate $\bar{r}_{t}$, and park excess reserves at the IOER facility to earn the remuneration rate $\underline{r}_{t}$ (the IOER rate). The interest rates of the marginal lending facility and the IOER facility are set so that they define the ceiling and the floor for interest rates of overnight interbank loans, hence building a corridor with the width corridor $_{t}=\bar{r}_{t}-\underline{r}_{t}$. However, non-euro-area banks (non-EA banks hereafter) do not have access to the Eurosystem's standing facilities and may trade at interest rates outside the corridor.

Assume that each trading session lasts a day and that for each trading day, each lender bank $i \in N$ is randomly matched with only one borrower bank $j \in N$, and that each loan is of the same euro-denominated value (scaled to one). ${ }^{14}$ At the end of the trading day, each EA (borrower and lender) bank has the outside option to draw on the central bank's standing facilities to cover its liquidity needs or invest excess funds. On the other hand, non-EA banks have no access to the Eurosystem's standing facilities, as discussed above.

The bargaining problem that the borrower bank and lender bank face can be represented in a generalized Nash-type solution setup (Binmore 1992; Bech and Klee 2011). The bargaining problem between a lender bank $i$ and a borrower bank $j$ at time $t$ can be defined as a tuple $(R, d) \in S$, where $R$ denotes the set of feasible bargaining outcomes, and $d=\left(d^{l}, d^{b}\right)$ is the threat point that determines the value of the outside options for the lender bank and borrower bank if the two parties fail to reach an agreement. For any given interbank loan, this means that the lender bank and borrower bank bargain over the interest rate $r \in R$ that the borrower will

\footnotetext{
${ }^{14}$ We focus on only the pricing and abstract from the detailed structure of the matching process and the forces behind interbank market participation that determine whether a bank supplies or demands funds. Similarly, we abstract from decisions about the loan volumes.
} 
need to pay to the lender for obtaining funding. In this context, the unique solution to the bargaining problem is determined by the function $f: S \rightarrow R$. With profit-maximizing, risk-neutral agents, the utility of agents resulting from a trade simply equals the interest income, such that the generalized Nash solution can be written as:

$$
r_{i, j, t}=\underset{d_{i, t}^{l} \leq r \leq d_{j, t}^{b}}{\arg \max }\left(r-d_{i, t}^{l}\right)^{\theta_{i, j, t}}\left(-r+d_{j, t}^{b}\right)^{1-\theta_{i, j, t}},
$$

where $\theta_{i, j, t} \in(0,1)$ denotes the bargaining power of the lender bank (over the borrower bank), and $1-\theta_{i, j, t}$ is the bargaining power of the borrower bank (over the lender bank). Hence, whenever the lender's bargaining power increases, the borrower's bargaining power decreases, and vice versa. Therefore, changes in $\theta_{i, j, t}$ are always associated with a shift in bilateral bargaining power from one bank to the other. Also note that $\theta_{i, j, t}=1$ corresponds to the situation where the lender has full bargaining power over the borrower.

The solution to the convex optimization problem is characterized by the first-order condition that we rearrange to obtain

$$
r_{i, j, t}=\left(1-\theta_{i, j, t}\right) d_{i, t}^{l}+\theta d_{j, t}^{b}=d_{i, t}^{l}+\theta_{i, j, t}\left(d_{j, t}^{b}-d_{i, t}^{l}\right) .
$$

The outside option of any EA bank (to draw on the central bank facilities at the end of the day) is given by the all-in cost of the standing facilities of the Eurosystem, that is, $\left(d_{i, t}^{l}, d_{j, t}^{b}\right)=\left(\underline{r}_{t}\right.$ , $\bar{r}_{t}$ ). Therefore, the interest rate between EA banks (from EA lender to EA borrower) can be written as

$$
r_{i, j, t}=\left(1-\theta_{i, j, t}\right) \underline{r}_{t}+\theta_{i, j, t} \bar{r}_{t}=\underline{r}_{t}+\theta_{i, j, t} \text { corridor }_{t} \forall i, j \in N^{E A} .
$$

That is, the bilaterally agreed interest rate of the loan between two EA banks equals the Eurosystem's IOER facility rate plus a spread that depends on the width of the interest rate corridor and the bank-pair bargaining power of the lender bank $\theta_{i, j, t}$. If two EA banks agree on the pricing of the loan, the interest rate should not be lower than the rate paid on excess reserves.

Non-EA lender banks have no outside investment options for reserves held in excess, as they cannot draw on the Eurosystem's IOER facility. The threat point between non-EA lenders and EA borrowers is thus given by $\left(d_{i, t}^{l}, d_{j, t}^{b}\right)=\left(0, \bar{r}_{t}\right) .{ }^{15}$ Substituting the outside options into Equation (1) leads to the following interest rate between non-EA lenders and EA borrowers:

$$
r_{i, j, t}=\theta_{i, j, t} \bar{r}_{t}=\theta_{i, j, t} \underline{r}_{t}+\theta_{i, j, t} \text { corridor }_{t} \forall i \in N^{n o n-E A}, j \in N^{E A},
$$

\footnotetext{
15 Setting the outside options for non-EA lender banks to zero can be seen as a conservative approach. In principle, a non-EA bank may also convert euros into the currency of its home country and earn the IOER rate paid by its central bank (if the foreign central bank has an IOER policy), potentially hedging the resulting FX risk with a forward contract. Consistent with heterogeneous outside options depending on the IOER rate in the non-EA bank's home country, Appendix Figure A.2 shows a negative relationship between the interest rate spread on a loan relative to the euro IOER rate and the spread between the euro IOER rate and the IOER rate in the bank's home country.
} 
which is a function of the euro area's interest rate corridor width, the Eurosystem's interest rate paid on excess reserves, and the bilateral bargaining power.

From these bilaterally agreed upon equilibrium interest rates, we can derive several comparative statics that will guide our empirical analysis.

Prediction 1: $\frac{\partial r_{i, j, t}}{\partial \text { corridor }_{t}}>0, \forall i, j \in N$. The interest rates charged by both $E A$ and non-EA lender banks increase as the width of the interest rate corridor of the Eurosystem increases.

Prediction 2: $\frac{\partial r_{i, j, t}}{\partial \underline{r}_{t}}>0, \forall i, j \in N$. The interest rates charged by both the EA and non-EA lender banks increase with the level of the interest rate paid on excess reserves. At the same time, $\underline{r}_{t}>0 \Rightarrow \frac{\partial r_{i, j, t}}{\partial \underline{r}_{t}}>\frac{\partial r_{i^{\prime}, j, t}}{\partial \underline{r}_{t}} \forall i, j \in N^{E A}$ and $i^{\prime} \in N^{n o n-E A}$, suggesting that this effect should be weaker for non-EA lender banks.

Prediction 3: $\underline{r}_{t}>0 \Rightarrow r_{i, j, t}<r_{i^{\prime}, j, t} \forall i \in N^{n o n-E A}$ and $i^{\prime}, j \in N^{E A}$. The interbank money market for overnight loans becomes segmented in terms of prices if the euro area's IOER facility rate is positive.

Prediction 4: $\frac{\partial r_{i, j, t}}{\partial \theta_{i, j, t}}>0, \forall i, j \in N$. Lenders with greater bargaining power relative to their borrowers are able to negotiate higher interest rates.

Prediction 5: $\underline{r}_{t}>0 \Rightarrow \frac{\partial r_{i, j, t}}{\partial \theta_{i, j, t}}>\frac{\partial r_{i^{\prime}, j, t}}{\partial \theta_{i, j, t}} \forall i \in N^{n o n-E A}$ and $i^{\prime}, j \in N^{E A}$. The interest rates are more sensitive to the bargaining power of non-EA lender banks if the euro area's IOER facility rate is higher than the non-EA bank's outside option (which is zero).

Prediction 6: $\frac{\underline{r}_{t}}{\text { corridor }_{t}}>\frac{\theta_{i, j, t}}{1-\theta_{i, j, t}} \Rightarrow r_{i, j, t}<\underline{r}_{t}, \forall i \in N^{n o n-E A}, j \in N^{E A}$. The rates charged by non-EA lenders can fall below the euro area's IOER facility rate if the bargaining power of the lender is sufficiently small. Hence, the interest rate paid on excess reserves does not provide a floor on euro overnight loans granted from borrowers from non-EA countries.

It is important to highlight that the determination of the interest rate for the loan between any two banks relies on the following features: (1) the lender and borrower bank have (direct 
or indirect) access to TARGET2 and can transfer euros to one another; (2) the borrower (EA) bank has access to the Eurosystem's IOER facilities to cover unmet liquidity needs or earn the IOER rate; and (3) non-EA lenders have the outside investment option of depositing end-ofday euros at an annualized rate of return of 0 percent. This last assumption may seem stark, but it could be relaxed to depend on the IOER rate in the non-EA lender's home country without losing the main message of the paper; see also Appendix Figure A.2.

A necessary condition for the differences in the interest rates that EA lenders and nonEA lenders charge (Prediction 3) is the existence of bargaining power in the interbank market. In a frictionless world where borrower banks engage in Cournot-type competition $\left(\theta_{i, j, t} \rightarrow 1\right)$, borrower bargaining positions and thus segmentation aspects would fade away as every lender provides loans at an interest rate that equals the outside options of the borrower banks, irrespective of the lender's outside options. Therefore, persistent interest rate differentials between EA lenders and non-EA lenders can only be the result of the existing difference in bargaining power. We next test the model's predictions using our loan-level data.

\subsection{EMPIRICAL EVALUATION}

We start our empirical analysis by looking at summary statistics. Table 1 shows that EA lender banks negotiate rates that on average are higher than those of non-EA lender banks. Moreover, interest rates for EA lender banks settle more than 31.7 basis points above the prevailing IOER rate on average, while overnight loans by non-EA lending banks settle about 16.4 basis points above the IOER rate. In Figure 1, we show the evolution of the spread between the interest rates of EA-lenders and those of non-EA lenders graphically. The spread between these interest rates is consistently positive and amounts to values of as much as 50 basis points. This interest rate differential is economically sizable and has important consequences for banks' financing conditions, as 22.6 percent of all loans are provided by non-EA lender banks, where the loan amounts are comparable across both groups. Thus, based on this initial finding, prices appear to be segmented in the euro-area interbank lending market. Based on our model predictions and the unique loan-level data, we next examine the role that differences in bargaining power and outside options play in this segmentation of prices.

To that end, we examine the pricing of interbank overnight loans in a linear regression framework using the following specification:

$$
\left(\text { Rate }_{i, j, t}-\text { IOER }_{t}\right)=\alpha+\beta^{\prime} x_{i, j, t}+\text { fixed effects }+u_{i, j, t},
$$

where Rate is the interest rate of the loan (in percent) between lender $i$ and borrower $j$ at day $t$, $u_{i, j, t}$ is an error term, and $x$ is a vector that includes the following set of independent variables 
dictated by our model: (1) the width of the interest rate corridor, Corridort, and (2) the level of the interest rate paid on excess reserves (IOER rate), $r_{\mathrm{t}}$. Note that by including these two variables, we are not assuming that the ECB moves the IOER and the corridor independently (although there were instances during our sample period when the ECB did change the rate on the marginal lending facility and the rate on the deposit facility in different ways). Rather, we use the equivalent formulation of the model with the IOER rate and the corridor width to study the variation in the IOER while controlling for the width of the interest rate corridor. Thus, we empirically measure the partial derivative (not the total derivative) of interest rate spreads with respect to an IOER rate change. Moreover, we define a dummy variable $n o n E A-E A$ i,j that equals the value of one if the loan is between a non-EA lender and an EA borrower, and zero if it is between an EA lender and an EA borrower. As a proxy for the lender's and borrower's bargaining power $\left(\theta_{i, j, t}\right)$, we use the lending and the borrowing concentration, respectively, measured by the Herfindahl-Hirschman index, or HHI (for example, Afonso, Kovner, and Schoar 2013). The HHI equals the sum of the squared bank-pair lending and borrowing shares, respectively. Hence, an HHI close to one indicates a highly concentrated interbank portfolio, and an HHI close to zero a highly diversified interbank portfolio. In accordance with our model explained above, we associate a bank's HHI with its bargaining power as follows: A high HHI of the lender bank suggests a highly concentrated portfolio and thus a low $\theta_{i, j, t}$, that is, low bargaining power of the lender and high bargaining power of the borrower; a high HHI for a borrower bank corresponds to a lower $1-\theta_{i, j, t}$, that is, lower bargaining power of the borrower, which corresponds to higher bargaining power of the lender. We compute the HHI variables based on a rolling window of the previous 30 days, but the results are very robust to using longer or shorter windows. Finally, we interact our proxy for bargaining power with the nonEA$E A_{\mathrm{i}, \mathrm{j}}$ dummy.

In our tightest specification, we further control for a common time variation in interest rates by including day fixed effects. Moreover, we include borrower-lender-pair fixed effects to control for time-invariant bank-pair specific heterogeneity, such as previous trading relationships (Ashcraft and Duffie 2007; Cocco et al. 2009; Afonso, Kovner, and Schoar 2013; Bräuning and Fecht 2017) and geographic distance (Degryse and Ongena 2005). Note that bank-pair fixed effects absorb bank fixed effects, for the borrower and for the lender, respectively. More specific to interbank networks though, market power might come from an institution's centrality in the interbank network (Craig and von Peter 2010) or the time needed to find a counterparty (Afonso and Lagos 2015). These drivers, however, are relatively constant over time and thus 
will be captured by bank-specific fixed effects. We estimate Equation 2 by ordinary least squares. ${ }^{16}$

Consistent with our model's first prediction, we show in column 1 of Table 2 that the interest rate on an overnight loan increases with the width of the interest rate corridor. In column 2, we include the IOER rate to test our model's second prediction, that is, whether the interest rates charged by both the EA and non-EA lender banks increase with the interest rate paid on excess reserves. The positive and significant point estimate indicates that if the central bank raises the outside options (that is, reduces the shadow cost), the interbank spreads also will increase. Our estimates indicate that an increase of 50 basis points in the corridor width is associated with an increase of 22.78 basis points in the loan spread, while an increase of 25 basis points in the IOER rate is associated with an increase of 3.58 basis points in the loan spread.

We next estimate the effect of differences in outside options on interbank rates. In line with model prediction 3, we show in column 3 of Table 2 that the interest rate is lower if the lender bank is a non-EA bank that does not have access to the IOER facility as compared with loan rates between an EA lender and EA borrower. In economic terms, the difference in the interest rates amounts to 15.16 basis points on average. Note that we estimate a differential effect between EA and non-EA lenders while abstracting from heterogeneity in outside options among non-EA lenders that could depend on the home countries' IOER rate (Appendix Figure A.2). Interestingly, our estimated coefficient from column 4 suggests (also in accordance with our second prediction) that the reaction of interbank loan rates to variations in the ECB's IOER is larger among EA-lenders than among non-EA lenders. In column 5, we test whether greater bargaining power is associated with more favorable loan terms by including the borrower's and lender's HHI as a proxy for their individual bargaining power. Consistent with prediction 4, we find that both lenders and borrowers with greater bargaining power over their respective counterparts are able to negotiate more favorable terms, that is, higher rates for lenders and lower prices for borrowers. ${ }^{17}$ These results are robust to the inclusion of time fixed effects (see column 6). In this specification, we estimate that the interest rate differential between non-EA lender banks and EA lender banks amounts to as much as 10.30 basis points.

Our model analysis suggests that the lender's bargaining power is more relevant for the interest rate determination if the lender does not have access to outside options (prediction 6).

\footnotetext{
${ }^{16}$ We provide robust standard errors in all tables. Our main results are robust against single-clustered standard errors at the bank-pair level and double-clustering at the bank-pair and day levels.

${ }^{17}$ Recall from Section 3.2 that a high HHI of the lender bank suggests a highly concentrated portfolio and thus a low $\theta$, that is, low bargaining power of the lender, while a high HHI for a borrower bank indicates lower bargaining power of the borrower, that is, higher bargaining power of the lender.
} 
We therefore examine whether our proxy for bargaining power has a stronger effect on rates for non-EA lenders. Indeed, as shown in column 7, we find that the coefficients of the interaction terms Lender's HHI*Dummy(nonEA-EA) and Borrower's HHI*Dummy(nonEA-EA) are statistically significant and carry a negative sign. This suggests that non-EA lender banks with a higher lending concentration (that is, that have particularly little bargaining power over their EA borrowers) will obtain significantly lower rates compared with a bank with a similar lending concentration but with access to the IOER facility. Similarly, EA borrower banks with high bargaining power can obtain significantly lower interest rates from their non-EA lenders compared with what they have to pay to EA lender banks, suggesting that bargaining power contributes to a segmentation of prices in the euro-area money market. This key result is robust to the inclusion of bank-pair fixed effects in addition to time fixed effects (column 8), which absorb any time-invariant borrower, lender, or bank-pair heterogeneity. Therefore, in the specification with bank-pair fixed effects, the level effects of the portfolio concentration variables (HHIs) are identified from changes over time within a given bank pair only and not from the cross section. Indeed, in this specification we find that unlike non-EA lenders, EA lenders with a higher HHI obtain higher interest rates, potentially because these lenders shop around to some degree for trades that offer higher returns. ${ }^{18}$

Our model's notion is that if the non-EA lender has limited (or no) bargaining power relative to the borrower, the interest rate for an overnight loan is low and can even fall below the IOER rate of the Eurosystem (prediction 6). Figure 2 provides evidence for the existence of such interbank money market trades that settle below the IOER rate in the euro area. In Table 1, we see that every third transaction (33.4 percent) between non-EA lenders and EA borrowers is conducted at an interest rate below the IOER rate; more than 5 percent of these non-EA lending trades are conducted at more than 10 basis points below the IOER rate. ${ }^{19}$ Moreover, in Figure 2 we see that toward the end of our sample, more than 90 percent of non-EA-to-EA loans have interest rates below the IOER rate, while the below-IOER-rate trades disappear when the IOER rate is set to zero, and, hence, there is no difference in the outside options of EA lenders and non-EA lenders (Appendix Figure A1). Note, however, that these differences in outside

\footnotetext{
${ }^{18}$ In Appendix Table A2, we show that our results are robust to the inclusion of pair*time trends. Moreover, one may have the notion that our measure for bargaining power can overlap with a proxy for lending relationship (for example, Cocco et al. 2009). To that end, we replicate in Appendix Table A2 our analysis from Table 2 column 8, but additionally control for bilateral lender preference index (LPI) and borrower preference index (BPI) measures, in both levels and interactions, to show that our results also withstand the inclusion of these two relationship-lending variables used in earlier literature.

${ }^{19}$ Less than 2 percent of transactions that are traded below the IOER rate are between EA lender and EA borrower banks. We have excluded those trades from our analysis. However, the results are quantitatively similar when we include them. Although a deeper analysis of the motive behind these trades is outside the scope of this paper, it could be related to reciprocal lending relationships and the associated insurance mechanism (Braeuning and Fecht 2017).
} 
options simply bring to the surface the deeper structural impact of the heterogeneity in bilateral bargaining power that induces the persistent price segmentation, as discussed in Section 3.1.

To examine the relationship between the below-IOER-rate trades and bargaining power more closely, we estimate the following linear probability model:

$$
\text { Below IOER Rate } e_{i, j, t}=\alpha+\beta^{\prime} x_{i, j, t}+\text { fixed effects }+u_{i, j, t} \text {, }
$$

where Below IOER Rate is a binary variable that equals the value of one for any loan between lender $i$ and borrower $j$ at day $t$ with a negotiated interest rate below the IOER rate prevailing on that day, and zero otherwise. The vector $x$ includes the same explanatory variables as in Equation (2).

In columns 1 and 2 of Table 3, we show that a larger corridor, as well as a higher IOER rate, decreases the probability of a loan occurring at a rate below the IOER rate. In column 3, we show that loans between non-EA lenders and EA borrowers have a statistically significantly larger probability of occurring below the IOER rate. The estimated coefficient indicates an economically sizable increase of 31.4 percentage points if the lender does not have access to the IOER facility. In column 4, we show that this effect is stronger if the IOER rate is at a low level. Similarly, in columns 5 and 6 we show that bargaining power drives the probability of belowIOER-rate trades. In economic terms, a lender with the highest lending concentration is about 6.7 percentages points more likely to grant an interest rate below the IOER rate (see column 6). Column 7 shows that this effect results from the non-EA lenders. When an EA borrower has bargaining power over a non-EA lender, there is a higher probability that it will be able to borrow funds at a rate below the IOER rate. Column 8 shows that this key result is robust to the inclusion of bank-pair fixed effects. (The change in the level effect for the lender's HHI resembles the finding in Table 2, column 8.)

Our findings suggest that the different outside options for non-EA lender banks (as compared with EA lender banks), in combination with the existence of bilateral bargaining power, create an arbitrage opportunity for EA borrowers. The basic mechanism of this arbitrage trade is that non-EA lenders lend euro funds to EA borrowers at lower rates due to their limited outside options and lack of sufficient bargaining power. For these non-EA lenders, any nonzero, positive interest rate exceeds the 0 percent they would otherwise earn by leaving the excess end-of-day funds on their balance accounts. This means that the interest rate for a loan between a non-EA lender and an EA borrower can indeed fall below the IOER rate. How far below the prevailing IOER rate it settles depends on the lender's bargaining power over the borrower (or, equivalently, the borrower's bargaining power over the lender). 
An EA bank that borrows funds from a non-EA lender at a rate below the IOER facility rate could deposit these additional funds at the IOER facility and earn the corresponding IOER rate from the Eurosystem, thereby making a risk-free spread. We test this arbitrage mechanism by examining each bank's daily recourse to the IOER facility and study how the amount of these deposits depends on interbank conditions, in particular on the amount the bank borrowed in the interbank market at an interest rate below the IOER rate. We use the following linear model:

Excess Reserves Held at IOER Facility ${ }_{j, t}=\alpha+\beta^{\prime} x_{j, t}+$ fixed effects $+u_{j, t}$,

where Excess Reserves Held at IOER Facility is the (logarithm of the) excess reserves held at the IOER facility by bank $\mathrm{j}$ at day $\mathrm{t}$ to earn the Eurosystem's IOER rate. The vector of independent variables $\mathrm{xj}, \mathrm{t}$ includes both the $(\log )$ amount of interbank credit borrowed below and above the IOER rate by bank $\mathrm{j}$ on day $\mathrm{t}$ before going to the IOER facility at the end of day $\mathrm{t}$. We also include the average price paid by each bank on below-IOER-rate loans and aboveIOER-rate loans as controls and include bank and day fixed effects.

Table 4 presents the estimation results. In columns 1 through 3, we show a positive and significant relationship between trades below the IOER rate and the reserves transferred to the IOER facility by the end of the business day. We find that for every given euro borrowed on that given day below the IOER rate, 25.2 euro cents are held at the IOER facility at the end of the business day to earn the overnight IOER rate paid by the Eurosystem (column 3). The estimated coefficient suggests an elasticity of less than 1: About a quarter of funds borrowed below the IOER rate are held at the IOER facility. This suggests that a large share of the borrowed funds are used to settle other transaction that may have an even higher return than the IOER facility. We also find that banks that borrow more funds in the interbank market at a rate above the prevailing IOER rate hold significantly smaller excess reserves in their deposit facility accounts. Also, the economic effects are quantitatively smaller than they are for the amount of funds borrowed below the IOER rate.

A potential concern with our specification could be that the amount borrowed below the IOER facility rate is endogenous to interbank borrowing conditions, thereby potentially biasing our coefficient estimate. In column 4, we therefore use an IV regression and instrument, for each bank, the amount borrowed below the IOER rate with the number of its non-EA lenders that do not have access to the Eurosystem in the period of July 1, 2008, through December 31, 2008. This instrument is exogenous to the reserves actually transferred to the IOER facility (our left-hand variable). Moreover, due to the high persistence in interbank lending relationships, 
for each bank, a larger number of non-EA lender counterparties in the reference period is associated with a larger number of non-EA lenders on any subsequent day in the sample, and thereby is associated with more funds borrowed from these non-EA banks at a rate below the IOER rate. Using this IV regression, we find qualitatively similar but quantitatively slightly larger effects: Out of every euro borrowed below the prevailing IOER rate, we estimate, banks deposit 36.5 euro cents at the IOER facility at the end of the business day. These results provide a new insight into the motives and distribution of reserve holdings across different institutions: Some banks hold large excess reserves due to persistent arbitrage, as described in this paper.

\section{Bargaining Power ANd Monetary Policy Implications}

The previous results show that bilateral bargaining power plays a key role in the pricing of OTC-traded interbank loans in the euro-area money market. Understanding bargaining power is therefore important for determining which factors promote or hamper the proper functioning of the interbank market and the transmission of monetary policy. In this section, we more closely examine the determinants of bargaining power and evaluate the implications for the effect of monetary policy changes on interbank lending rates.

\subsection{Understanding the Variation in Bargaining Power}

To examine the bank-pair, bank, and time dimensions of bargaining power in more detail, we first rearrange Equation (1) to back out the bargaining parameter $\theta_{\mathrm{i}, \mathrm{j}, \mathrm{t}}=\frac{\mathrm{r}_{\mathrm{i}, \mathrm{j}, \mathrm{t}}-\mathrm{d}_{\mathrm{i}, \mathrm{t}}^{\mathrm{l}}}{\mathrm{d}_{\mathrm{j}, \mathrm{t}}^{\mathrm{b}}-\mathrm{d}_{\mathrm{i}, \mathrm{t}}^{\mathrm{l}}} \cdot \operatorname{Recall}$ that $\theta_{\mathrm{i}, \mathrm{j}, \mathrm{t}}$ measures the bilateral bargaining power that lender $i$ exercises over borrower $j$ at day $t$. As before, $\theta_{\mathrm{i}, \mathrm{j}, \mathrm{t}} \in(0,1)$ denotes the bargaining power of the lender bank, and $1-\theta_{\mathrm{i}, \mathrm{j}, \mathrm{t}}$ is the bargaining power of the borrower bank.

If we decompose the resulting bargaining power $\theta_{\mathrm{i}, \mathrm{j}, \mathrm{t}}$ in several dimensions, we find that about 60.8 percent of the overall variation in $\theta_{\mathrm{i}, \mathrm{j}, \mathrm{t}}$ can be attributed to day fixed effects and 30.9 percent to bank-pair fixed effects. Moreover, 20.6 percent can be attributed to bank-pair fixed effects after we control for day fixed effects. This suggests that our bargaining power measure has important heterogeneity at the time dimension but also at the bank-pair level, which cannot be explained by common time variables. This dimension can be analyzed only by disaggregating loan-level interbank lending data, which is what we do in the next step. ${ }^{20}$

\footnotetext{
${ }^{20}$ This is in line with how Furfine (2011) argues for the US federal funds market.
} 
To study the determinant of bargaining power more closely, we model the bilateral bargaining power using the following generalized linear estimation equation:

$$
E\left(\theta_{i, j, t}\right)=\frac{\exp \left(\beta^{\prime} x_{i, j, t}\right)}{1+\exp \left(\beta^{\prime} x_{i, j, t}\right)},
$$

where $\beta$ is a parameter vector, and $x$ includes the lending and borrowing concentration index HHI (Afonso, Kovner, and Schoar 2013). ${ }^{21}$ Additionally, we include respective quadratic terms of these variables to account for potential nonlinearities, motivated by the significant heterogeneity and asymmetry of the HHIs (see Table 1). To estimate the effects of monetary policy operations on bargaining power, we use the (logarithm of the) total amount outstanding associated with the Eurosystem's open market operations (that is, main refinancing operations and longer-term refinancing operations) and a binary variable that takes the value one on any day after October 15, 2008, when the Eurosystem introduced the fixed-rate, full-allotment (FRFA) policy. Given the documented interbank market segmentation, we estimate Equation (5) for non-EA-lender-EA-borrower pairs and EA-lender-EA-borrower pairs separately to account for potentially heterogeneous effects.

In column 1 of Table 5, we show that lenders (both EA and non-EA banks) with a higher $\mathrm{HHI}$ have less bargaining power over their respective borrowers, confirming that the $\mathrm{HHI}$ is a good proxy for bargaining power. The effect is quantitatively larger for non-EA banks (see column 3), indicating that specifically for these lenders, diversification in the interbank market helps with setting higher prices. Marginal effects at the means are presented in columns 1 through $4 .{ }^{22}$ In columns 2 and 4, we show an important nonlinearity in portfolio diversification: A strong borrowing concentration leads to more bargaining power for the non-EA lender, and vice versa. For EA lender banks, this effect is quantitatively smaller. This finding suggests that non-EA lenders, in contrast to EA lender banks, are much less able to use the lack of diversification of the EA borrower to set higher interest rates. In Figure 4, we graphically illustrate the effect of changes in lending and borrowing concentration on bargaining power.

Common to all specifications in columns 1 through 4 of Table 5 is that the Eurosystem's monetary policy affects bargaining power in the interbank market. Our results show that the

\footnotetext{
${ }^{21}$ In our robustness specifications, we use two different variables that are often used in the related literature. First, we use the borrower's borrower preference index (BPI) and the lender's lender preference index, LPI (for example, Cocco, Gomez, and Martins 2009). The BPI and the LPI measures for each bank pair the relative amount that they have been borrowing and lending to a given counterparty relative to the overall borrowing and lending volume, respectively, thereby accounting for existing trading partnerships and portfolio concentration (Afonso, Kovner, and Schoar 2013). Second, we compute the (indegree and out-degree) network centrality for both the borrower and the lender as the number of lenders with which the borrower maintains a trading relationship and the number of borrowers with which the lender maintains trading relationships (for example, Craig and von Peter 2014). The results are qualitatively similar.

${ }^{22}$ Marginal effects are valid for variables that enter linearly. For variables that also enter in quadratic terms, we plot the changes in bargaining power instead; see Figure 4.
} 
bargaining power of the lender bank (that is, $\theta_{\mathrm{i}, \mathrm{j}, \mathrm{t}}$ ) decreases when the Eurosystem increases its liquidity provision through open market operations. We also find that the introduction of the fixed-rate, full-allotment policy decreases primarily the bargaining power of the non-EA lender banks over their borrowers. We do not find a similarly strong effect for EA lenders. Moreover, we find that an increase in aggregate excess reserves decreases the bargaining power of both EA and non-EA lender banks. Further, we find that a borrower holding a larger share of the aggregate reserves has greater bargaining power over its lender banks. The effects for loans from non-EA lenders are qualitatively similar to those for loans from EA lenders. Finally, our results show that higher money market liquidity reduces the bargaining power of lender banks in the overnight lending market. Similarly, higher market liquidity associated with foreign exchange, bond, and equity markets reduces the bargaining power of lenders.

Given the importance of outside options and bargaining power for determining interbank lending rates, we next elaborate on various euro-area monetary policy scenarios and derive possible outcomes for the overnight price of interbank funding in the euro area.

\subsection{IMPliCATION FOR MONETARY POLICY}

As a starting point, we compute the quantity-weighted average of the interest rate charged by a typical EA lender and the interest rate charged by a typical non-EA lender. The premise of this approach is that looking at an average interest rate that does not account for the segmentation (as documented above) in money markets can be misleading. Let $\lambda^{\mathrm{EA}}$ denote the fraction of loans granted by euro-area lenders, then the average interest rate $r_{\mathrm{t}}$ is given by:

$$
r_{t}=\lambda_{t}^{E A} r_{E A, E A, t}+\left(1-\lambda_{t}^{E A}\right) r_{n o n-E A, E A, t}
$$

where $r_{E A, E A, t}$ is the typical interest rate charged by EA lenders, and $r_{n o n-E A, E A, t}$ is the typical interest rate charged by non-EA lenders. Following our Nash bargaining model from Section 3, the bank-pair interest rate is $r_{i, j, t}=r\left(\underline{r}_{t}, \bar{r}_{t}, x_{i, j, t}\right)$, with $\mathrm{r}($.$) given in Equation (1). For loans$ between EA lenders and EA borrowers, we compute the interest rate evaluated at the mean value of the variables as $r_{E A, E A, t}=r\left(\underline{r}_{t}, \bar{r}_{t}, \tilde{x}_{i, j, t}\right)$, where $\tilde{x}_{i, j, t}$ is the mean of the covariates for the pairs of EA lenders and EA borrowers, while we compute the interest rate between non-EA lenders and EA borrowers as $r_{n o n-E A, E A, t}=r\left(0, \bar{r}_{t}, \hat{x}_{i, j, t}\right)$, with $\hat{x}_{i, j, t}$ being the mean of the covariates for the pairs of non-EA lenders and EA borrowers.

In Figure 5, we present the possible outcomes for the (effective) overnight interest rate in response to changes in the IOER rate and the excess reserves provided to the banking sector. 
For our analysis, we use values for the monetary policy instruments that we actually observe during our sample period. We set the corridor width at 1.5 percent for the analysis of the pricing of overnight loans (as changes to the corridor width will have only a level effect). We analyze the role of loans provided by non-EA lenders while considering the following scenarios: (1) low market participation (12.9 percent of all loans granted by non-EA lenders) and (2) high market participation (33.7 percent of all loans granted by non-EA lenders) based on the empirical distribution borne out by the data. ${ }^{23}$

The overall finding can be summarized as follows: (1) the effective interest rate is positively related to a decrease in the supply of excess reserves by the central bank, but the effect of a change in excess reserves is nonlinear and stronger for lower levels of excess reserves; (2) an increase (or decrease) in the interest rate paid on excess reserves increases (decreases) the effective overnight interest rate; (3) if monetary policy changes these two measures at the same time, the impact on the effective average overnight rate will be stronger than a change of either one of the measures alone; (4) the effect of a change in the IOER rate is less strong in the case of high non-EA lender bank participation. High non-EA lender participation reduces the financing costs of EA borrower banks, and the higher the level of the IOER rate, the more pronounced the effect is. This shows that looking at an average rate, such as the Eonia ${ }^{24}$, that does not take into account the documented money market segmentation can be misleading in assessing euro area banks' true financing costs. This has important implications, as the Eonia (or any other effective average rate) is considered the standard reference rate for the unsecured money market, which also serves as the benchmark for the pricing of fixed-income securities throughout the economy and determines short-term retail bank interest rates as well as mortgage rates (for example, Sorensen and Werner 2006).

In Figure 6, we use our estimated bargaining model to further analyze the implications of the heterogeneity in banks' bargaining power and outside options for monetary policy. We do this by considering the interest rate reaction to monetary policy changes for three different kinds of representative bank pairs: (1) a lender with a low lending concentration (lender's HHI is at the 5th percentile) and a borrower with a low borrowing concentration (borrower's HHI is at the 5th percentile), (2) a lender with a high lending concentration (HHI at the 95th percentile) and a borrower with a low borrowing concentration (HHI at the 5th percentile), and (3) a lender

\footnotetext{
${ }^{23}$ We also analyze the effects of policy changes using a simple model of non-EA lender participation. The results (not reported) are qualitatively similar.

${ }^{24}$ In the euro area, the Eonia is based on transactions from a panel of 35 selected banks; see www.euribor.org. Non-EA lenders are underrepresented (or not included at all) in this computation, hence suggesting that the Eonia is upward biased and does not reflect the actual price of overnight funds for euro-area banks.
} 
with a low lending concentration (HHI at the 5th percentile) and a borrower with a high borrowing concentration ( $\mathrm{HHI}$ at the 95 th percentile).$^{25} \mathrm{We}$ analyze this type of heterogeneity at the bank-pair level for the non-EA-lender-to-EA-borrower pairs and EA-lender-to-EA-borrower pairs separately.

Our results show that the group of EA-to-EA bank pairs exhibits a strong heterogeneity in bargaining power; lenders with a low lending concentration that provide credit to borrowers with a high borrowing concentration exhibit the strongest bargaining power. Heterogeneous bargaining effects are, however, less pronounced when large excess reserves are held in the euro-area banking sector. But, if excess reserves decrease to zero (or close to zero, as was the case before the financial crisis), the lenders' bargaining power increases for all groups. In addition, we find that the within-group heterogeneity increases substantially. For example, the bargaining power of high-HHI borrowers when borrowing from low-HHI lenders is about 0.1 smaller than that of low-HHI borrowers. With an interest rate corridor width of, say, 1.5 percent, this corresponds to a 15 basis point difference. Figure 6 also shows that the documented effects are quantitatively similar when the Eurosystem abolishes its fixed-rate, full-allotment policy in favor of the variable-rate tender with a price discriminatory auction setup (dashed lines).

For non-EA-lenders-to-EA-borrowers bank pairs, we find qualitatively similar results regarding the heterogeneity in bargaining power, but we document quantitatively less withingroup heterogeneity as compared with EA-lender-to-EA-borrower pairs. Moreover, the bargaining power of non-EA lenders reacts more strongly to changes in monetary policy measures. First, a reduction in excess reserves leads to a stronger increase in bargaining power compared with EA lenders for all three different bank pairs. Second, the within-group heterogeneity in bargaining power actually diminishes once excess reserves are reduced to zero. Third, abolishing the fixed-rate, full-allotment policy would shift the bargaining power toward non-EA lenders by about 0.2 . In economic terms, in a world without the fixed-rate, full-allotment policy, the interest rate at which non-EA banks lend out overnight funds to EA banks would be about 30 basis points higher.

Alternatively, one may think that our previous reduced-form approach does not address the fact that market power is endogenous to the ECB's liquidity stance. The key question then is whether greater market power, market segmentation, or both influence the transmission of the ECB IOER and liquidity stance to interbank loan rates. Therefore, in Appendix Table A2,

\footnotetext{
${ }^{25}$ These three stylized pairs correspond to the empirically relevant situation that we know from the 'core-periphery' interbank network topology context, where two very active banks in the interbank market engage with each other (case (i)), or one of the counterparties is very active and well connected, while the counterparty is not (cases (ii) and (iii)).
} 
we show the reaction of loan rates to the IOER rate and the corridor width depending on exante (that is, lagged) market power and on the "(Dummy) Non-EA to EA," and on their interaction. The results in all three columns of Table A2 are in line with our prediction and suggest that greater market power can indeed affect the transmission of monetary policy.

Overall, our policy analysis shows that the effectiveness of monetary policy in the euro area crucially depends on the heterogeneity in banks' bargaining power and outside options, both of which have an important economic impact on the pricing of overnight funds in the wholesale funding market. Policymakers should therefore take these heterogeneous effects into account when making policy decisions.

\section{CONCLUSION}

Many central banks implement monetary policy in a way that maintains a close relationship between reserve balances and an average short-term interest rate. However, we argue that the interest rates in the over-the-counter (OTC) interbank market may vary strongly across market participants depending on the different outside options and especially the bilateral bargaining power of both the lender and the borrower of a given trade, thereby affecting monetary policy implementation and its transmission to the wider economy.

We use a proprietary data set on the euro-area interbank market to establish the following robust key results: (1) lenders with more bargaining power than their borrowers are able to negotiate higher interest rates; (2) lenders with outside options (that is, access to the Eurosystem's facilities) charge higher interest rates (about 10 basis points higher on average) for overnight loans compared with their peers without such access; (3) the negotiated interest rates are more sensitive to the bargaining power of the lender bank if that institution has no outside investment options; and (4) interest rates can fall below the Eurosystem's IOER rate if the bargaining power of the lender is sufficiently small and the lender has no outside options. Persistent opportunity for arbitrage can arise only when these banks persistently provide funds at a rate below the IOER rate, inducing a segmentation of prices for central bank reserves in the euroarea interbank market.

As a consequence of this segmentation in interbank rates, some banks face substantially different financing cost than is suggested by the official average effective overnight rate (Eonia), thereby affecting the transmission of monetary policy. In particular, our results suggest that the effects of any policy related to a tightening of euro-area monetary policy-either through an unwinding of unconventional policy or through an interest rate increase - crucially 
depend on banks' alternative outside options and especially the bilateral bargaining power of participating banks at that time in the interbank market. Indeed, our analysis shows that substantial participation by banks without access to the IOER facility will exert downward pressure on interbank rates when the IOER moves back into positive territory (and different outside options become relevant). On the other hand, a large reduction of excess reserves will shift bargaining power from borrowers to lender banks and thus increase interbank rates.

More generally, our finding that interbank rates vary substantially depending on bilateral bargaining power suggests that for the transmission of monetary policy, it is important to consider, using transaction-level data, the variation in financing cost in the interbank market across different banks. Our findings are also relevant for the discussion of the optimal counterparty framework for the conduct of monetary policy, as the bargaining power of direct counterparties of the central bank in monetary operations (such as the primary dealers in the United States versus a wider set of eligible counterparties, for example, in the euro area) will affect the pass-through of monetary policy measures to broader financial markets and the economy. This is particularly important as credit supply (at both the extensive and intensive margins) to nonfinancial firms is shaped by all banks participating in the financial system (for example, Jiménez et al. 2019, and the references therein). In fact, one may argue that banks without outside investment options and low bargaining power may be hampered in their ability to pass on favorable credit conditions to the nonfinancial sector, thereby competing with the effect of monetary policy on real economic outcome variables. These results are also important as they reveal that the effect of bilateral bargaining power is important irrespective of the prevailing monetary policy implementation framework, that is, a reserve regime (for example, the US Fed, the Bank of Japan) versus an interest rate corridor regime (for example, the ECB, the Bank of England).

Finally, our results are relevant for the discussion about the size of central banks' balance sheets when policy rates move away from their current low levels. Because the impact of heterogeneity in bargaining power on the pricing of interbank loans decreases when the supply of central bank reserves is large, our findings advocate a floor system under a relatively large balance sheet of the respective central bank if the objective is to contain the variation in bilateral interest rates. However, in such a framework, it would be crucial to establish an infrastructure that ensures a single, level playing field across all market participants with respect to the access policy, and thus to the alternative investment options carrying the same interest rate. 


\section{REFERENCES}

Abbassi, P., F. Bräuning, F. Fecht, and J.-L. Peydró. 2014. "Cross-border Liquidity, Relationships and Monetary Policy: Evidence from the Euro Area Interbank Crisis." Bundesbank Discussion Papers 45/2014.

Abreu, D., and M. Manea. 2012. "Bargaining and Efficiency in Networks." Journal of Economic Theory 147(1): 43-70.

Acharya, V. V., D. Gromb, and T. Yorulmazer. 2012. "Imperfect Competition in the Interbank Market for Liquidity as a Rationale for Central Banking." American Economic Journal: Macroeconomics 4(2): 184-217.

Afonso, G. M., A. Kovner, and A. Schoar. 2013. "Trading Partners in the Interbank Lending Market.” Federal Reserve Bank of New York Staff Report 620.

Afonso, G., and R. Lagos. 2015. "Trade Dynamics in the Market for Federal Funds.” Econometrica 83(1): 263-313.

Allen, F., and A. Babus. 2008. "Networks in Finance." Wharton Financial Institutions Center Working Paper 08-07.

Arciero, L., R. Heijmans, R. Huever, M. Massarenti, C. Picillo, and F. Vacirca. 2013. "How to Measure the Unsecured Money Market? The Eurosystem's Implementation and Validation Using TARGET2 Data.” International Journal of Central Banking 12(1): 247-280.

Armantier, O., and A. Copeland. 2012. "Assessing the Quality of Furfine-based Algorithms." Federal Reserve Bank of New York Staff Report 575.

Ashcraft, A.B, and D. Duffie. 2007. "Systemic Illiquidity in the Federal Funds Market." American Economic Review 97(2): 221-225.

Atkeson, A. G., A. L. Eisfeldt, and P.-O. Weill. 2015. "Entry and Exit in OTC Derivatives Markets." Econometrica 83(6): 2231-2292.

Bech, M. L., and E. Atalay. 2010. "The Topology of the Federal Funds Market." Physica A: Statistical Mechanics and Its Applications 389(22): 5223-5246.

Bech, M.L., and E. Klee. 2011. "The Mechanics of a Graceful Exit: Interest on Reserves and Segmentation in the Federal Funds Market." Journal of Monetary Economics 58(5): 415-431.

Bech, M.L., E. Klee, and V. Stebunovs. 2012. "Arbitrage, Liquidity and Exit: The Repo and Federal Funds Markets Before, During, and Emerging from the Financial Crisis." Finance and Economics Working Paper 2012-21.

Bech, M., and C. Monnet. 2016. "A Search-based Model of the Interbank Money Market and Monetary Policy Implementation.” Journal of Economic Theory 164(July): 32-67.

Berentsen, A., and C. Monnet. 2008. "Monetary Policy in a Channel System." Journal of Monetary Economics 55(6): 1067-1080. 
Bindseil, U. 2004. Monetary Policy Implementation: Theory, Past, and Present. New York: Oxford University Press.

Bindseil, U., and J. Lablecki. 2011. "The Optimal Width of the Central Bank Standing Facilities Corridor and Banks’ Day-to-day Liquidity Management.” ECB Working Paper 1350.

Blasques, F., F. Bräuning, and I. V. Lelyveld. 2016. “A Dynamic Network Model of the Unsecured Interbank Lending Market.” Federal Reserve Bank of Boston Working Paper 16-3.

Bräuning, F., and F. Fecht. 2017. "Relationship Lending in the Interbank Market and the Price of Liquidity." Review of Finance 21(1): 33-75.

Chiu, J., and C. Monnet. 2016. "Relationships in the Interbank Market." Bank of Canada Staff Working Paper 16-33.

Cocco, J. F., F. J. Gomes, and N. C. Martins. 2009. "Lending Relationships in the Interbank Market." Journal of Financial Intermediation 18(1): 24-48,

Craig, B., and G. v. Peter. 2014. "Interbank Tiering and Money Center Banks." Journal of Financial Intermediation 23(3): 322-347.

Duffie, D., N. Garleanu, and L. H. Pedersen. 2005. "Over-the-counter Markets." Econometrica 73(6): 1815-1847.

Fricke, D., and L., Thomas. 2012. "Core-periphery Structure in the Overnight Money Market: Evidence from the e-MID Trading Platform.” Kiel Working Paper 1759.

Friedman, B. M., and K. N. Kuttner. 2011. "Implementation of Monetary Policy: How Do Central Banks Set Interest Rates?" In. Handbook of Monetary Economics Vol. 3, edited by B.M Friedman, B.M. and M. Woodford, 1345-1438. Amsterdam, the Netherlands: Elsevier.

Furfine, C. H. 1999. "The Microstructure of the Federal Funds Market." Financial Markets, Institutions \& Instruments 8(5): 24-44.

Furfine, C. H. 2001. "Banks as Monitors of Other Banks: Evidence from the Overnight Federal Funds Market.” Journal of Business 74(1): 33-57.

Furfine, C. 2011. "Comment on: 'The Mechanics of a Graceful Exit."' Journal of Monetary Economics 58(5): 432-435.

Goodfriend, M. 2002. "Interest on Reserves and Monetary Policy." Economic Policy Review 8(1): 77-84.

Iori, G., R. N. Mantegna, L. Marotta, S. Miccichè, J. Porter, and M. Tumminello. 2015. "Networked Relationships in the e-MID Interbank Market: A Trading Model with Memory. Journal of Economic Dynamics and Control 50(January): 98-116.

Iyer, R., and J.-L. Peydró. 2011. "Interbank Contagion at Work: Evidence from a Natural Experiment. Review of Financial Studies 24(4): 1337-1377. 
Iyer, R., J.-L. Peydró, S. da-Rocha-Lopes, and A. Schoar. 2014. "Interbank Liquidity Crunch and the Firm Credit Crunch: Evidence from the 2007-2009 Crisis." Review of Financial Studies 27(1): 347-372.

Jiménez, G., Mian, A., Peydró, J.-L., and J. Saurina. 2020. “The Real Effects of Bank Lending Channel.” Journal of Monetary Economics. Forthcoming.

Keister, T., A. Martin, and J. McAndrews. 2008. "Divorcing Money from Monetary Policy." Economic Policy Review 14(2): 41-56.

Kraenzlin, S.P., and T. Nellen. 2015. "Access Policy and Money Market Segmentation.” Journal of Monetary Economics 71(April): 1-12.

Langfield, S., Z. Liu, and T. Ota. 2014. “Mapping the UK Interbank System.” Journal of Banking and Finance 45(August): 288-303.

Rørdam, K.B., and M.L. Bech. 2009. “The Topology of Danish Interbank Money Flows.” University of Copenhagen Finance Research Unit Working Paper 09-01.

Vayanos, D., and P.-O. Weill. 2008. "A Search-based Theory of the On-the-run Phenomenon." Journal of Finance 63(3): 1361-1398.

Whitesell, W. C. 2006a. "Monetary Policy Implementation without Averaging or Rate Corridors." Finance and Economics Discussion Series 2006-22, Board of Governors of the Federal Reserve System.

Whitesell, W. C. 2006b. "Interest Rate Corridors and Reserves.” Journal of Monetary Economics 53(6): 1177-1195.

Zhu, H. 2012. "Finding a Good Price in Opaque Over-the-counter Markets." Review of Financial Studies 25(4): 1255-1285. 


\section{FigURES}

FIGURE 1: INTEREST RATE SPREAD BETWEEN EA AND NON-EA LENDERS

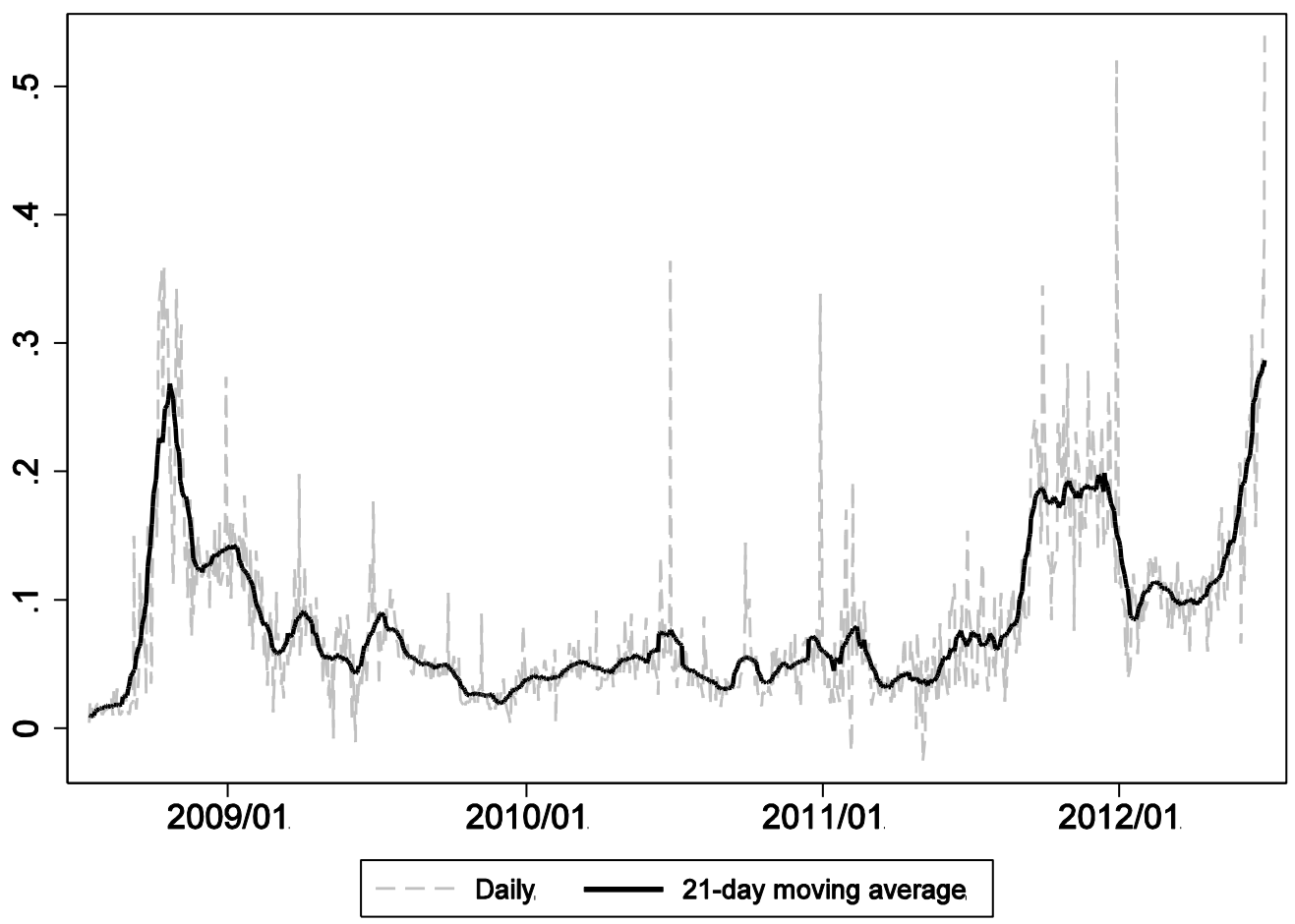

Notes: This figure depicts the daily (equally weighted) average spread (gray dashed line, in percent) between the interest rates that EA lender and non-EA lender banks charge for an overnight credit during the sample from July 1, 2008, through June 29, 2012. It also shows the 21-day moving average (black solid line) spread. 
FiguRE 2: Fraction OF TRADES BELOW THE IOER RATE

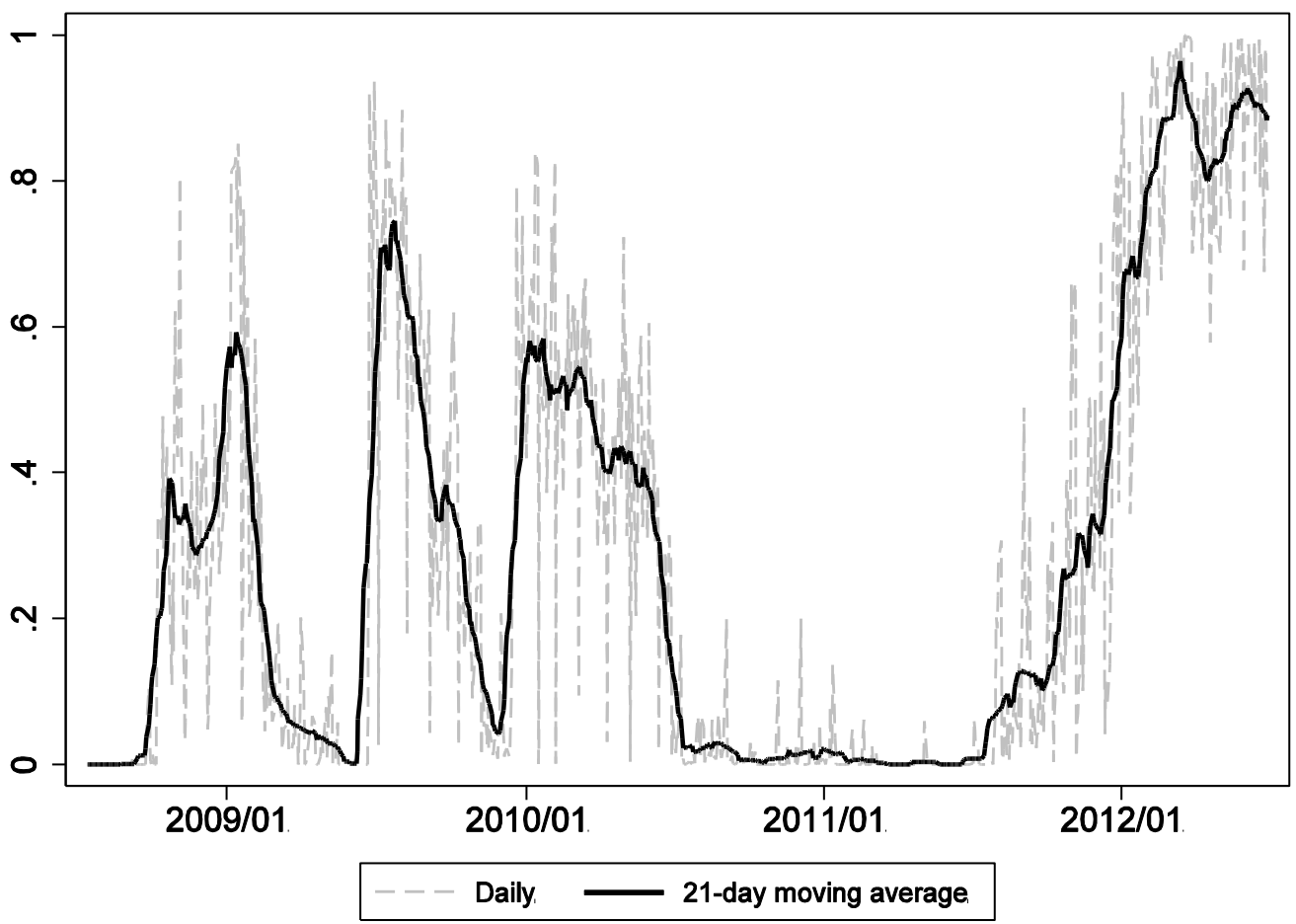

Notes: This figure presents the evolution of EA lenders' daily total loan amount lent at rates below the IOER rate as a fraction of their daily total loan amount (gray dashed line) in our sample from July 1, 2008, through June 29, 2012. It also shows the 21-day moving average (black solid line). 
Figure 3: Histogram of LENDER BARgaining Power AT THE BANK-PAIR LEVEL

(A) EA LENDER BANKS

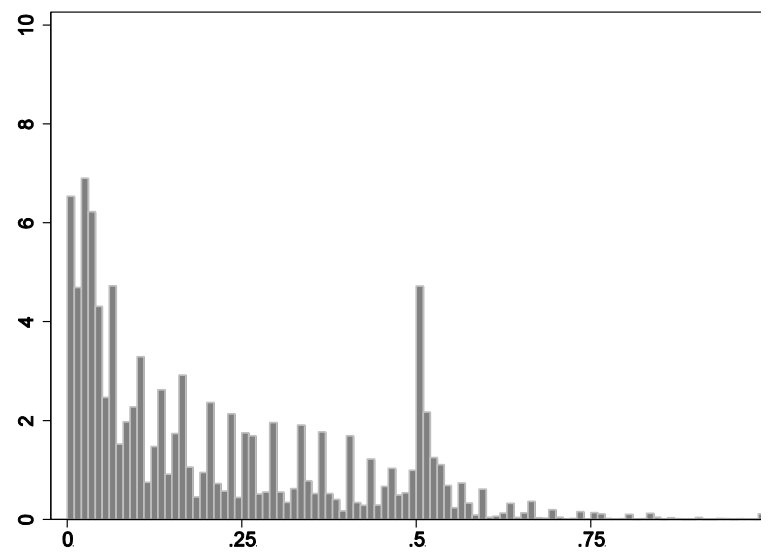

(B) NON-EA LENDER BANKS

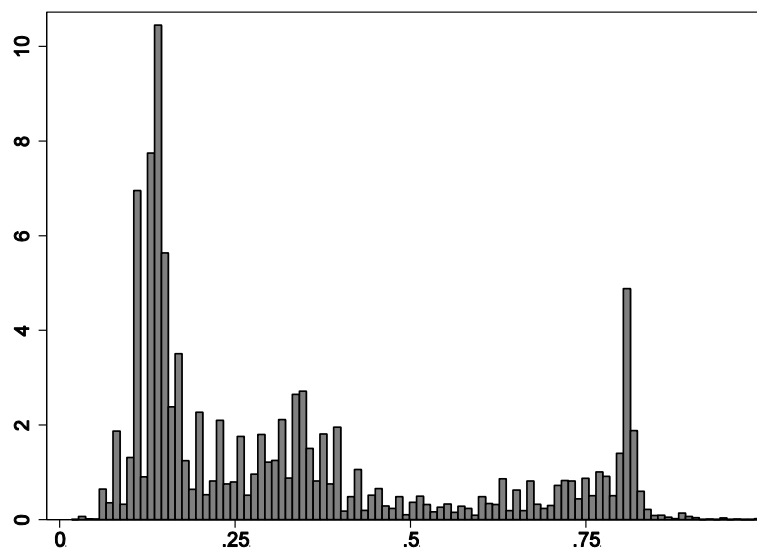

Notes: Subfigure (a) shows the histogram of the (equally weighted) average of the bilateral bargaining power, $\theta_{\mathrm{i}, \mathrm{j}, \mathrm{t}}$, of EA lender banks in our sample from July 1, 2008, through June 29, 2012. Subfigure (b) reflects the histogram of the (equally weighted) average of the bilateral bargaining power of non-EA lender banks for the same sample. 


\section{FIGURE 4: IMPACT OF LENDERS’ AND BORROWERS’ CONCENTRATION ON LENDER BARGAINING POWER}

(A) LENDER's HHI

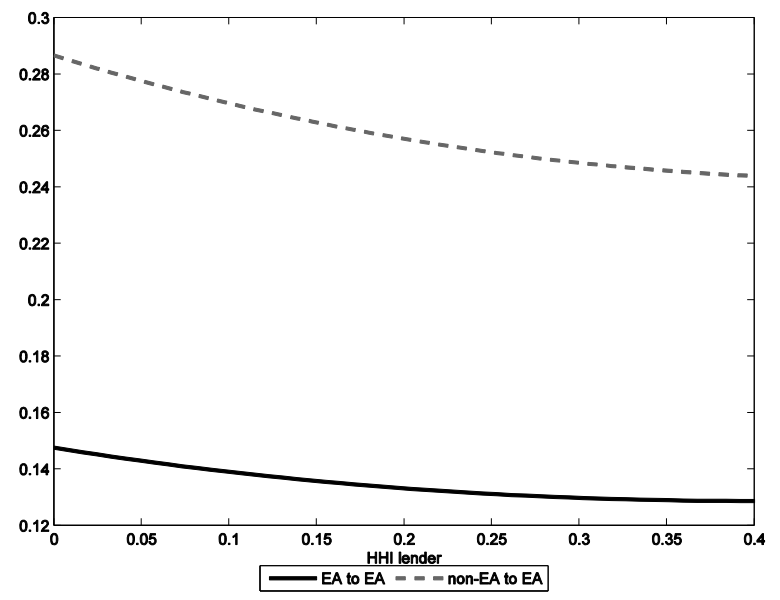

(B) BORROWER'S HHI

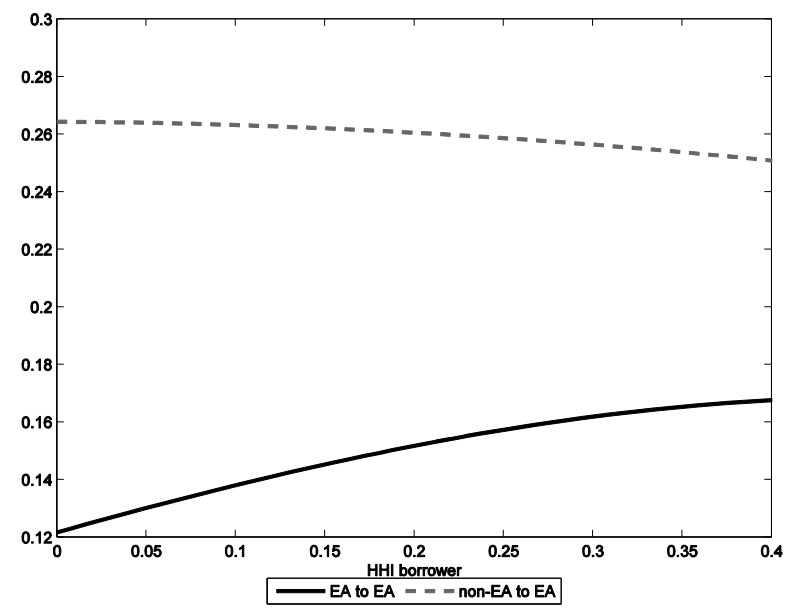

Notes: Subfigure (a) refers to the estimated effect of lenders' HHI on lenders' bargaining power $\left(\theta_{\mathrm{i}, \mathrm{j}, \mathrm{t}}\right)$ presented in columns 2 and 4 of Table 5. The black solid line refers to the sample of loans between an EA lender and EA borrower (column 2), and the gray dashed line is based on the sample of loans between a non-EA lender and an EA borrower (column 4). Subfigure (b) reflects the estimated effect of borrowers' HHI on lenders' bargaining

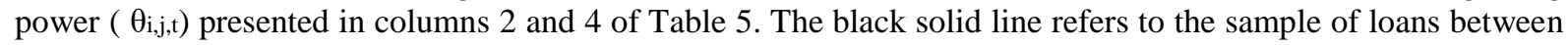
an EA lender and an EA borrower (column 2), and the gray dashed line is based on the sample of loans between a non-EA lender and an EA borrower (column 4). 


\section{FIGURE 5: POSSIBLE OUTCOMES FOR THE EFFECTIVE EUROPEAN OVERNIGHT RATE IN RESPONSE TO MONETARY POLICY CHANGES}
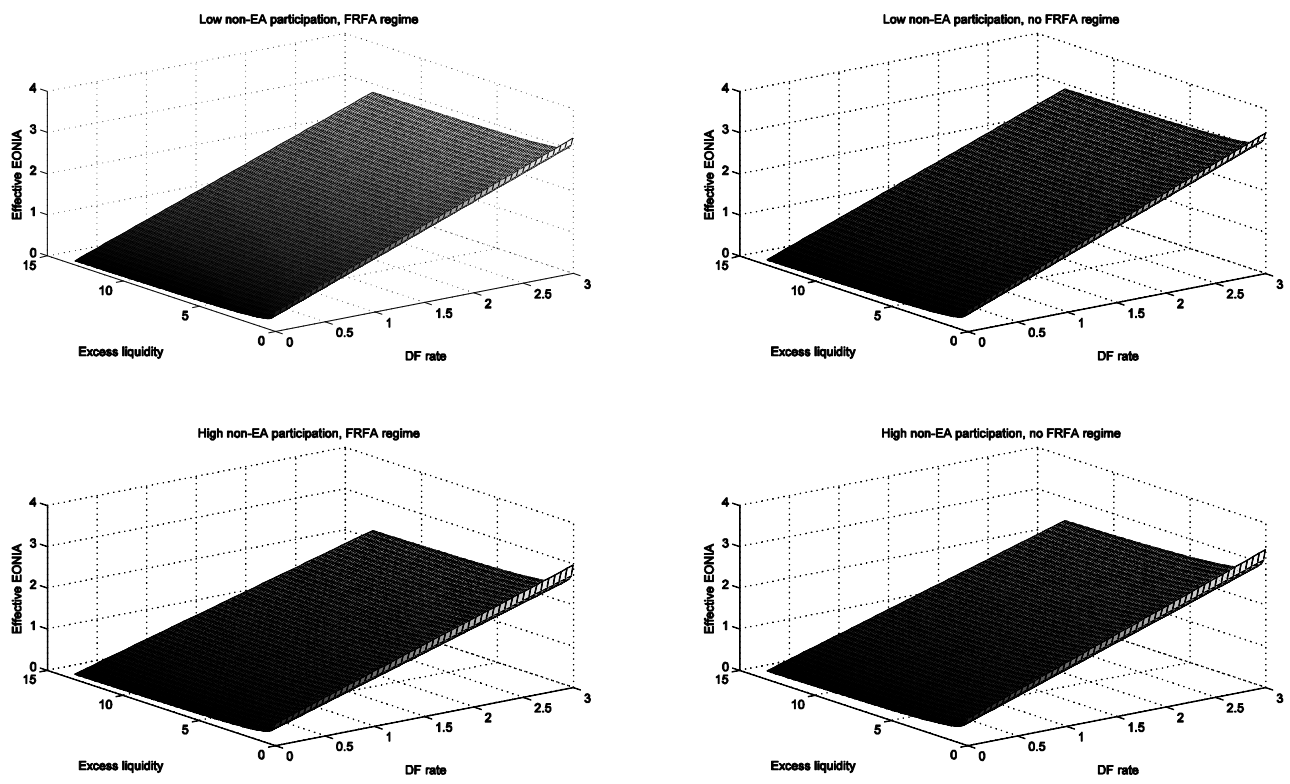

Notes: This figure presents the set of possible outcomes for the effective European overnight rate, Eonia, (z-axis, in percent) in response to monetary policy changes, for example, changes in the excess reserves (y-axis, in logarithm of billion Euros) available to the banking sector, changes in the IOER rate (x-axis, in percent), and a potential switch from the fixed-rate, full-allotment policy to a variable-rate tender with price discrimination. The possible set of outcomes of the effective overnight rate is constructed for four different cases: (1) low non-EA participation under the FRFA regime (upper-left panel), (2) low non-EA participation and abolishing the FRFA regime (upperright panel), (3) high non-EA participation under the FRFA regime (lower-left panel), and (4) high non-EA participation and abolishing the FRFA regime (lower-right panel). 
FIGURE 6: CHANGES IN LENDER BARGAINING POWER IN RESPONSE TO MONETARY POLICY CHANGES

(A) EA LENDER TO EA BORROWER

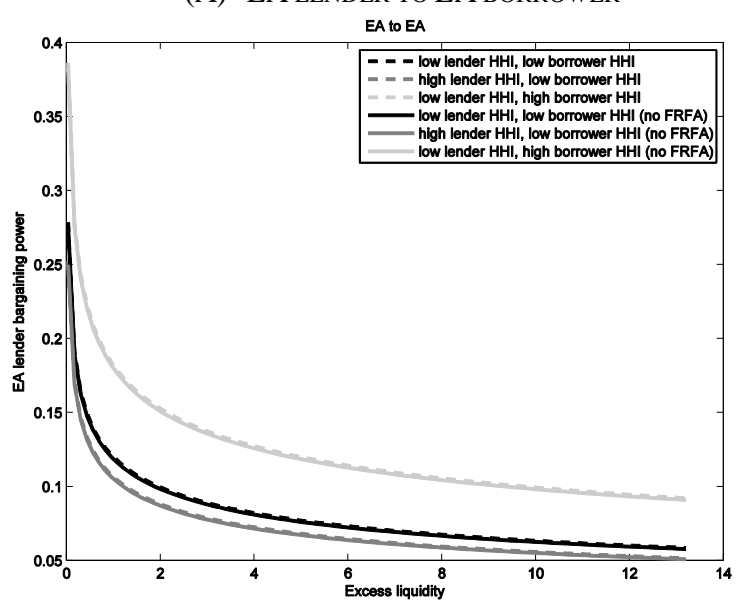

(B) NON-EA LENDER TO EA BORROWER

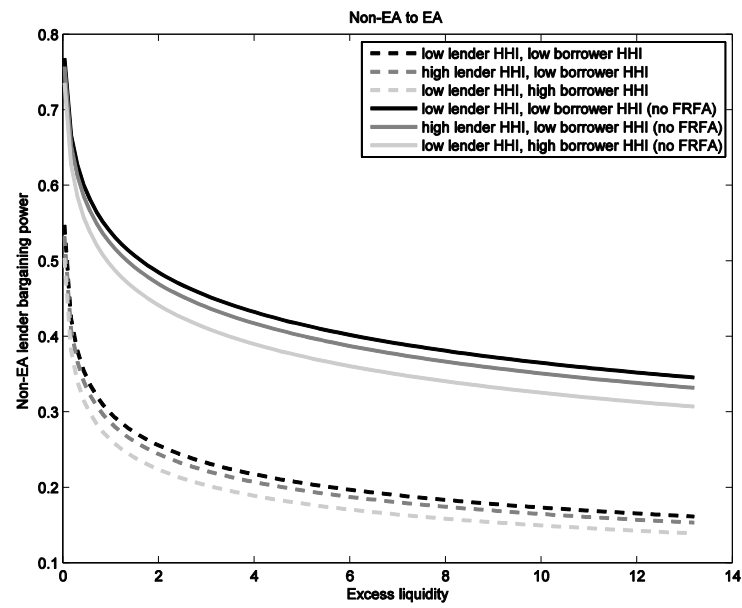

Notes: Subfigure (a) shows how the bargaining power of the EA lender changes in response to monetary policy changes, for example, changes in the excess reserves provided by the Eurosystem and abolishing the FRFA policy. Subfigure (b) presents how the bargaining power of the non-EA lender changes in response to monetary policy changes, for example, changes in the excess reserves provided by the Eurosystem and abolishing the FRFA policy. 


\section{TABLES}

TABLE 1 - SUMMARY STATISTICS

\begin{tabular}{|c|c|c|c|c|}
\hline Loan characteristics of EA lender banks: & Mean & Std. & $\mathrm{p} 5 \%$ & $\mathrm{p} 95 \%$ \\
\hline Rate - IOER & 0.317 & 0.323 & 0.010 & 1.030 \\
\hline Amount & 10.332 & 1.394 & 8.517 & 12.766 \\
\hline Theta & 0.199 & 0.191 & 0.007 & 0.550 \\
\hline Lender's HHI & 0.152 & 0.163 & 0.008 & 0.506 \\
\hline Lender's HHI^2 & 0.049 & 0.108 & 0.000 & 0.256 \\
\hline Borrower's HHI & 0.152 & 0.182 & 0.005 & 0.555 \\
\hline Borrower's HHI^2 & 0.056 & 0.131 & 0.000 & 0.308 \\
\hline Loan characteristics of non-EA lender banks: & Mean & Std. & $\mathrm{p} 5 \%$ & $\mathrm{p} 95 \%$ \\
\hline Rate - IOER & 0.164 & 0.309 & -0.100 & 0.990 \\
\hline Amount & 10.885 & 1.331 & 8.700 & 13.102 \\
\hline Theta & 0.320 & 0.230 & 0.111 & 0.810 \\
\hline Lender's HHI & 0.243 & 0.204 & 0.016 & 0.642 \\
\hline Lender's HHI^2 & 0.101 & 0.154 & 0.000 & 0.412 \\
\hline Borrower's HHI & 0.118 & 0.162 & 0.003 & 0.481 \\
\hline Borrower's HHI^2 & 0.040 & 0.110 & 0.000 & 0.231 \\
\hline$\underline{\text { Interbank market characteristics }}$ & Mean & Std. & $\mathrm{p} 5 \%$ & $\mathrm{p} 95 \%$ \\
\hline IOER & 0.663 & 0.863 & 0.250 & 3.250 \\
\hline Marginal lending facility & 2.191 & 0.884 & 1.750 & 4.250 \\
\hline Corridor width & 1.528 & 0.220 & 1.000 & 2.000 \\
\hline Fraction non-EA trades & 0.226 & 0.067 & 0.129 & 0.337 \\
\hline Fraction non-EA trades below IOER rate & 0.334 & 0.328 & 0.000 & 0.900 \\
\hline Amount outstanding associated with OMOs (in logs) & 6.434 & 0.275 & 6.034 & 6.888 \\
\hline FRFA_dummy & 0.946 & 0.226 & 0.000 & 1.000 \\
\hline Excess reserves (in logs) & 18.239 & 1.702 & 16.033 & 20.459 \\
\hline Fraction reserve holdings & 0.002 & 0.013 & 0.000 & 0.009 \\
\hline FX, bond, and equity market liquidity & 0.068 & 0.307 & -0.590 & 0.340 \\
\hline Money market liquidity & -1.189 & 1.316 & -4.220 & 0.050 \\
\hline Last day of RMP & 0.051 & 0.220 & 0.000 & 1.000 \\
\hline
\end{tabular}

Notes: This table provides summary statistics on all main variables used in the paper covering the period from July 1, 2008, through June 29, 2012. In the upper panel of the table, we provide loan-level information on trades in which the lender bank is an EA bank. In the middle panel, we provide the same information on non-EA lender banks. In the bottom panel, we provide descriptive statistics on market-wide characteristics. Definitions of our main variables are provided in the Appendix Table A1 
TABle 2 - BARGAINING POWER, OUtSide Options, AND BILATERAL INTERest RATES

\begin{tabular}{|c|c|c|c|c|c|c|c|c|}
\hline & \multicolumn{8}{|c|}{ Dependent Variable: Rate - IOER } \\
\hline & (1) & (2) & (3) & (4) & $(5)$ & (6) & (7) & (8) \\
\hline Corridor width & $\begin{array}{c}49.815^{* * * *} \\
(0.25)\end{array}$ & $\begin{array}{c}31.229 * * * \\
(0.20)\end{array}$ & $\begin{array}{c}30.978 * * * \\
(0.19)\end{array}$ & $\begin{array}{c}28.414 * * * \\
(0.21)\end{array}$ & $\begin{array}{c}31.121 * * * \\
(0.19)\end{array}$ & & & \\
\hline IOER rate & & $\begin{array}{c}14.330 * * * \\
(0.04)\end{array}$ & $\begin{array}{c}14.314 * * * \\
(0.04)\end{array}$ & $\begin{array}{c}14.455^{* * * *} \\
(0.05)\end{array}$ & $\begin{array}{c}14.271 * * * \\
(0.04)\end{array}$ & & & \\
\hline Dummy (Non-EA to EA) & & & $\begin{array}{c}-15.157 * * * \\
(0.10)\end{array}$ & $\begin{array}{c}-31.534 * * * * \\
(0.69)\end{array}$ & $\begin{array}{c}-14.342 * * * \\
(0.10)\end{array}$ & $\begin{array}{c}-10.247 * * * \\
(0.05)\end{array}$ & $\begin{array}{c}-10.301 * * * \\
(0.05)\end{array}$ & \\
\hline Corridor width*Dummy (Non-EA to EA) & & & & $\begin{array}{c}11.482^{* * * *} \\
(0.46)\end{array}$ & & & & \\
\hline IOER rate* Dummy (Non-EA to EA) & & & & $\begin{array}{c}-0.593 * * * \\
(0.11)\end{array}$ & & & & \\
\hline Lender's HHI & & & & & $\begin{array}{c}-8.230 * * * \\
(0.30)\end{array}$ & $\begin{array}{c}-3.984 * * * \\
(0.18)\end{array}$ & $\begin{array}{c}-3.562 * * * \\
(0.20)\end{array}$ & $\begin{array}{c}1.909^{* * * *} \\
(0.22)\end{array}$ \\
\hline Borrower's HHI & & & & & $\begin{array}{c}1.935 * * * \\
(0.34)\end{array}$ & $\begin{array}{c}12.262 * * * \\
(0.23)\end{array}$ & $\begin{array}{c}11.930 * * * \\
(0.22)\end{array}$ & $\begin{array}{c}0.832^{* * * *} \\
(0.25)\end{array}$ \\
\hline Lender's HHI*Dummy (Non-EA to EA) & & & & & & & $\begin{array}{c}-2.605 * * * \\
(0.35)\end{array}$ & $\begin{array}{c}-4.442 * * * \\
(0.40)\end{array}$ \\
\hline Borrower's HHI*Dummy (Non-EA to EA) & & & & & & & $\begin{array}{c}-15.610^{* * * *} \\
(0.48)\end{array}$ & $\begin{array}{c}-4.173^{* * * *} \\
(0.51)\end{array}$ \\
\hline RMP fixed effects & Yes & Yes & Yes & Yes & Yes & - & - & - \\
\hline Loan amount control & Yes & Yes & Yes & Yes & Yes & Yes & Yes & Yes \\
\hline Time fixed effects & No & No & No & No & No & Yes & Yes & Yes \\
\hline Bank-pair fixed effects & No & No & No & No & No & No & No & Yes \\
\hline Observations & 371,805 & 371,805 & 371,805 & 371,805 & 371,805 & 371,805 & 371,805 & 371,805 \\
\hline R-squared & 0.150 & 0.342 & 0.378 & 0.379 & 0.379 & 0.826 & 0.827 & 0.899 \\
\hline
\end{tabular}

Notes: This table reports the least squares estimates of Equation 2. The dependent variable is the spread between the bilaterally negotiated interest rate of the loan between lender $i$ and borrower $j$ at day $t$ and the IOER facility rate (IOER rate) on the same day (in basis points). Robust standard errors are presented in parentheses. The definitions of all variables can be found in Table A1. 
TABle 3 - BARgAining POWER, OUtSide Options, AND BELOW-IOER TRADES

\begin{tabular}{|c|c|c|c|c|c|c|c|c|}
\hline & \multicolumn{8}{|c|}{ Dependent Variable: Below IOER Rate (0/1) } \\
\hline & (1) & (2) & $(3)$ & $(4)$ & $(5)$ & (6) & (7) & (8) \\
\hline Corridor width & $\begin{array}{c}-0.092 * * * \\
(0.00)\end{array}$ & $\begin{array}{c}-0.082^{* * *} \\
(0.00)\end{array}$ & $\begin{array}{c}-0.077 * * * \\
(0.00)\end{array}$ & $\begin{array}{c}0.002 * * * \\
(0.00)\end{array}$ & $\begin{array}{c}-0.078^{* * *} \\
(0.00)\end{array}$ & & & \\
\hline IOER rate & & $\begin{array}{c}-0.007 * * * \\
(0.00)\end{array}$ & $\begin{array}{c}-0.007 * * * * \\
(0.00)\end{array}$ & $\begin{array}{c}-0.000 * * * \\
(0.00)\end{array}$ & $\begin{array}{c}-0.006^{* * * *} \\
(0.00)\end{array}$ & & & \\
\hline Dummy (Non-EA to EA) & & & $\begin{array}{c}0.314 * * * \\
(0.00)\end{array}$ & $\begin{array}{c}0.943 * * * \\
(0.01)\end{array}$ & $\begin{array}{c}0.307 * * * \\
(0.00)\end{array}$ & $\begin{array}{c}0.291 * * * \\
(0.00)\end{array}$ & $\begin{array}{c}0.284 * * * \\
(0.00)\end{array}$ & \\
\hline Corridor width*Dummy (Non-EA to EA) & & & & $\begin{array}{c}-0.357 * * * \\
(0.01)\end{array}$ & & & & \\
\hline IOER rate*Dummy (Non-EA to EA) & & & & $\begin{array}{c}-0.033 * * * \\
(0.00)\end{array}$ & & & & \\
\hline Lender's HHI & & & & & $\begin{array}{c}0.092^{* * * *} \\
(0.00)\end{array}$ & $\begin{array}{c}0.067 * * * \\
(0.00)\end{array}$ & $\begin{array}{c}0.035 * * * * \\
(0.00)\end{array}$ & $\begin{array}{c}-0.039 * * * \\
(0.00)\end{array}$ \\
\hline Borrower's HHI & & & & & $\begin{array}{c}0.044 * * * \\
(0.00)\end{array}$ & $\begin{array}{c}0.009 * * * \\
(0.00)\end{array}$ & $\begin{array}{c}0.013 * * * \\
(0.00)\end{array}$ & $\begin{array}{c}0.042 * * * \\
(0.00)\end{array}$ \\
\hline Lender's HHI*Dummy (Non-EA to EA) & & & & & & & $\begin{array}{c}0.230 * * * \\
(0.01)\end{array}$ & $\begin{array}{c}0.114 * * * \\
(0.01)\end{array}$ \\
\hline Borrower's HHI*Dummy (Non-EA to EA) & & & & & & & $\begin{array}{c}0.210^{* * * *} \\
(0.01)\end{array}$ & $\begin{array}{c}0.339 * * * \\
(0.02)\end{array}$ \\
\hline RMP fixed effects & Yes & Yes & Yes & Yes & Yes & - & - & - \\
\hline Loan amount control & Yes & Yes & Yes & Yes & Yes & Yes & Yes & Yes \\
\hline Time fixed effects & No & No & No & No & No & Yes & Yes & Yes \\
\hline Bank-pair fixed effects & No & No & No & No & No & No & No & Yes \\
\hline Observations & 371,805 & 371,805 & 371,805 & 371,805 & 371,805 & 371,805 & 371,805 & 371,805 \\
\hline R-squared & 0.010 & 0.011 & 0.273 & 0.303 & 0.276 & 0.343 & 0.349 & 0.557 \\
\hline
\end{tabular}

Notes: The estimations presented in this table refer to Equation 3. The dependent variable is a binary variable that equals one for any loan between lender $\mathrm{i}$ and borrower $\mathrm{j}$ at day $\mathrm{t}$ that is traded at an interest rate below the IOER rate, and zero otherwise. Robust standard errors are presented in parentheses. The definitions of all variables can be found in Table A1. 
TABLE 4 - BELOW-IOER TRADES AND RECOURSE TO IOER FACILITY

\begin{tabular}{|c|c|c|c|c|c|}
\hline & \multicolumn{5}{|c|}{ Dependent Variable: Excess Reserves Held at IOER Facility } \\
\hline & \multicolumn{4}{|c|}{ Pooled OLS } & \multirow{2}{*}{$\frac{\text { IV regression }}{(5)}$} \\
\hline & (1) & (2) & (3) & (4) & \\
\hline Loan amount borrowed below IEOR rate & $\begin{array}{c}0.546 * * * \\
(0.01)\end{array}$ & $\begin{array}{c}0.487 * * * \\
(0.01)\end{array}$ & $\begin{array}{c}0.279 * * * \\
(0.01)\end{array}$ & $\begin{array}{c}0.252 * * * \\
(0.01)\end{array}$ & $\begin{array}{c}0.365 * * * \\
(0.01)\end{array}$ \\
\hline Loan amount borrowed above IOER rate & $\begin{array}{c}-0.020 * * * \\
(0.01)\end{array}$ & $\begin{array}{c}0.023 * * * \\
(0.01)\end{array}$ & $\begin{array}{c}-0.154 * * * \\
(0.01)\end{array}$ & $\begin{array}{c}-0.150^{* * * *} \\
(0.01)\end{array}$ & $\begin{array}{c}-0.058 * * * \\
(0.01)\end{array}$ \\
\hline (Rate - IOER) for borrowing below-IOER-rate & & & & $\begin{array}{c}-2.813^{* * * *} \\
(0.39)\end{array}$ & $\begin{array}{c}-1.582 * * * \\
(0.39)\end{array}$ \\
\hline (Rate - IOER) for borrowing above-IOER-rate & & & & $\begin{array}{c}0.229 * * * \\
(0.05)\end{array}$ & $\begin{array}{c}-0.161 * * * \\
(0.05)\end{array}$ \\
\hline RMP fixed effects & Yes & - & - & - & - \\
\hline Loan amount lent control & Yes & Yes & Yes & Yes & Yes \\
\hline Time fixed effects & No & Yes & Yes & Yes & Yes \\
\hline Bank-pair fixed effects & No & No & Yes & Yes & Yes \\
\hline Observation & 87,431 & 87,431 & 87,431 & 87,431 & 87,431 \\
\hline R-squared & 0.215 & 0.289 & 0.443 & 0.444 & 0.396 \\
\hline
\end{tabular}

Notes: This table shows the least squares estimates of Equation 4. The dependent variable is the (logarithm of the) amount parked at the IOER facility by bank $\mathrm{j}$ at day $\mathrm{t}$. "Loan amount borrowed below (above) IEOR rate" is the (logarithm of the) amount borrowed below (above) the IOER rate by bank $\mathrm{j}$ on day t. Robust standard errors are presented in parentheses. The definitions of all variables can be found in Table A1. 
TABLE 5 - Determinants of BILATERAL BARgaining Power

Dependent Variable: Theta

Lender's HHI

Borrowers's HHI

Lender's HHI^2

Borrowers's HHI^2

Amount outstanding associated with OMOs

FRFA dummy

Excess reserves (in logs)

Fraction reserve holdings

FX, bond, and equity market liquidity

Money market liquidity

Last day of RMP

\begin{tabular}{clcc}
\hline \multicolumn{4}{c}{ EA lending banks } \\
\hline Coef. & ME & Coef. & ME \\
\hline$(1)$ & $\left(1^{\prime}\right)$ & $(2)$ & $\left(2^{\prime}\right)$ \\
\hline
\end{tabular}

$-0.256 * * *$

$(0.02)$

$0.594 * * *$

(0.02)

$-0.036 * * *$

$0.084 * * *$

$(0.00)$

$-0.791 * * *$

$-0.111 * * *$

$(0.01)$

$1.638^{* * *} \quad 0.230^{* * * *}$

$(0.04)$

$(0.01)$
$0.139 * * *$

$\begin{array}{cc}(0.07) & (0.01) \\ -1.738 * * * & -0.245 * * *\end{array}$

(0.06) $\quad(0.01)$

$\begin{array}{cccc}-1.910^{* * *} & -0.269 * * * & -1.923 * * * & -0.271 * * * \\ (0.02) & (0.00) & (0.02) & (0.00) \\ 0.030^{* *} & 0.004 * * & 0.021^{*} & 0.003^{*} \\ (0.01) & (0.00) & (0.01) & (0.00) \\ -0.305^{* * *} & -0.043 * * * & -0.306 * * * & -0.043 * * * \\ (0.00) & (0.00) & (0.00) & (0.00) \\ -7.609 * * * & -1.072 * * * & -7.180 * * * & -1.010^{* * *} \\ (0.50) & (0.07) & (0.51) & (0.07) \\ -0.688^{* * *} & -0.097 * * * & -0.698^{* * *} & -0.098^{* * *} \\ (0.01) & (0.00) & (0.01) & (0.00) \\ -0.204^{* * *} & -0.029 * * * & -0.204 * * * & -0.029 * * * \\ (0.00) & (0.00) & (0.00) & (0.00) \\ 0.546 * * * & 0.089^{* * *} & 0.556 * * * & 0.091 * * * \\ (0.01) & (0.00) & (0.01) & (0.00) \\ & & & \end{array}$

291,163

\begin{tabular}{cccc}
\multicolumn{4}{c}{ Non-EA lending banks } \\
\hline Coef. & ME & Coef. & ME \\
\hline$(3)$ & $\left(3^{\prime}\right)$ & $(4)$ & $\left(4^{\prime}\right)$ \\
\hline$-0.278^{* * *}$ & $-0.058^{* * *}$ & $-0.939^{* * *}$ & $-0.195^{* * *}$ \\
$(0.01)$ & $(0.00)$ & $(0.03)$ & $(0.01)$
\end{tabular}

$-0.245^{* * *}$

$(0.00)$

$(0.00)$

$-0.010 \quad-0.002$

$(0.02)$

$0.979 * *$

$(0.01)$

(0.05) $\quad(0.01)$

$-0.420 * * * \quad-0.087 * * *$

$(0.07) \quad(0.02)$

$\begin{array}{llll}-0.755 * * * & -0.157 * * * & -0.752 * * * & -0.156 * * *\end{array}$

$\begin{array}{llll}(0.02) & (0.00) & (0.02) & (0.00)\end{array}$

$\begin{array}{llll}-1.012 * * * & -0.236 * * * & -1.008^{* * * *} & -0.235^{* * *}\end{array}$

$\begin{array}{llll}(0.01) & (0.00) & (0.01) & (0.00)\end{array}$

$\begin{array}{llll}-0.311^{* * *} & -0.065^{* * *} & -0.311^{* * *} & -0.065^{* * *}\end{array}$

$\begin{array}{cccc}(0.00) & (0.00) & (0.00) & (0.00)\end{array}$

$\begin{array}{llll}-3.359 * * * & -0.699 * * * & -3.286 * * * & -0.684 * * *\end{array}$

$\begin{array}{llll}(0.14) & (0.03) & (0.14) & (0.03)\end{array}$

$-1.099 * * \quad-0.229 * * * \quad-1.098 * * * \quad-0.228 * *$

$\begin{array}{llll}(0.01) & (0.00) & (0.01) & (0.00)\end{array}$

$\begin{array}{lccc}-0.371 * * * & -0.077 * * * & -0.372^{* * * *} & -0.077 * * *\end{array}$

$\begin{array}{llll}(0.00) & (0.00) & (0.00) & (0.00)\end{array}$

$\begin{array}{llll}0.544 * * * & 0.123 * * * & 0.545 * * * & 0.123 * * *\end{array}$

$\begin{array}{llll}(0.01) & (0.00) & (0.01) & (0.00)\end{array}$

$80,642 \quad 80,642$

Notes: This table reports coefficient estimates of Equation 5 along with marginal effects. The dependent variable is a nonlinear transformation of a linear index function that can take on values between zero and one. It measures the bilateral bargaining power between lender $\mathrm{i}$ and borrower $\mathrm{j}$ at day t. For each model, the first column presents the parameter

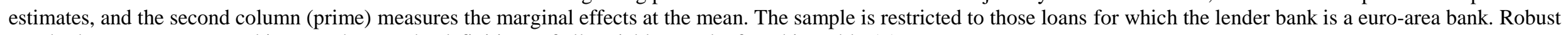
standard errors are presented in parentheses. The definitions of all variables can be found in Table A1. 


\section{APPENDIX}

\section{Figure A1 - Fraction OF TRADES BELOW THE IOER RATE}

BEFORE AND AFTER IOER RATE WAS SET TO ZERO

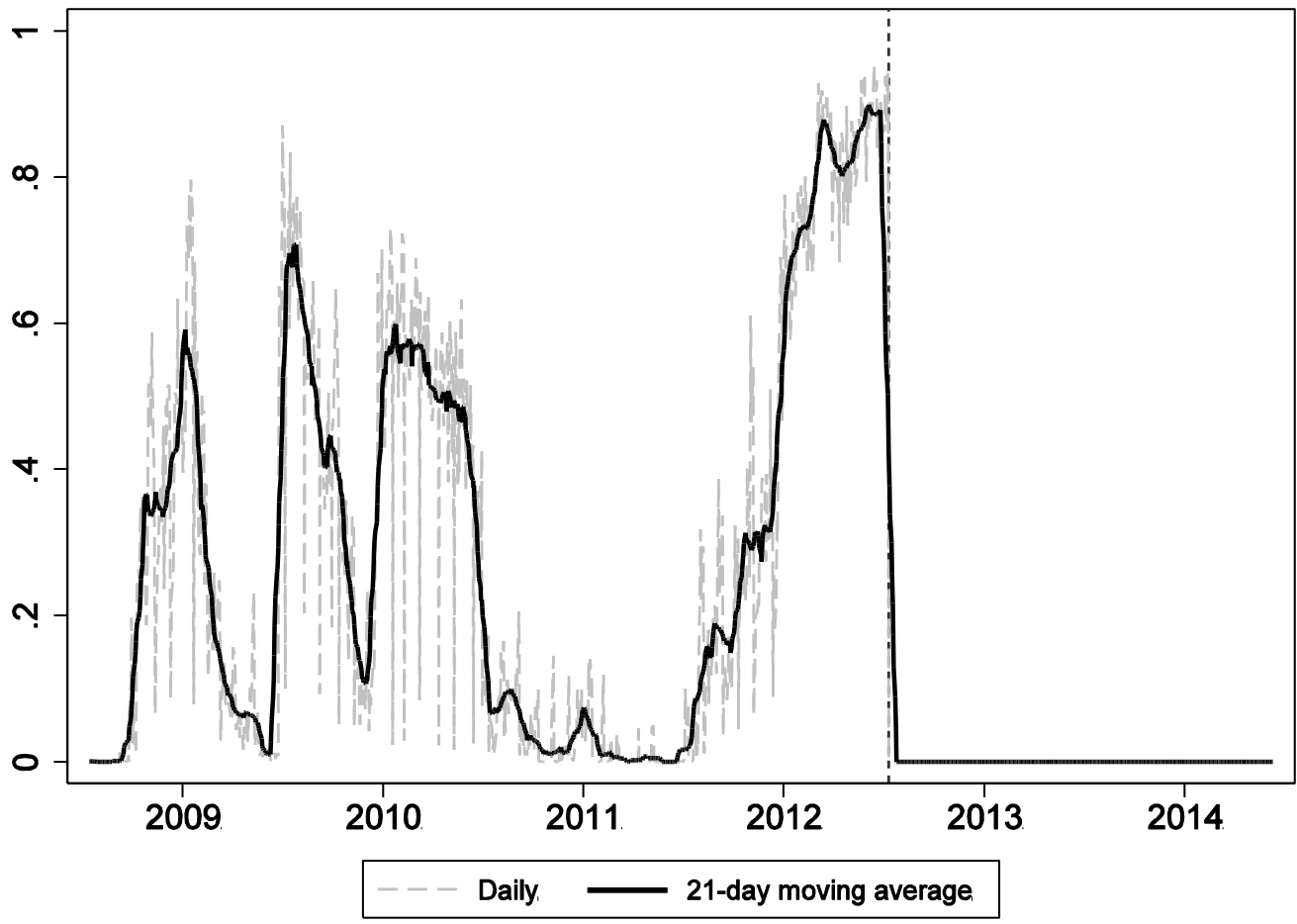

Notes: This figure presents the evolution of non-EA lenders' daily total loan amount lent at rates below the IOER rate as a fraction of their daily total loan amount (gray dashed line) in our sample from July 1, 2008, through June 2014. It also shows the 21-day moving average (black solid line). The dashed vertical line represents July 11, 2012 , when the Eurosystem set its IOER rate to 0 percent. 
FiguRE A2 - RELATIONSHIP BETWEEN INTEREST RATE SPREAD AND NON-EA BANKS’ OUTSIDE OPTIONS AS MEASURED B Y SPREAD BETWEEN IOER RATE IN EA AND NON-EA COUNTRY.

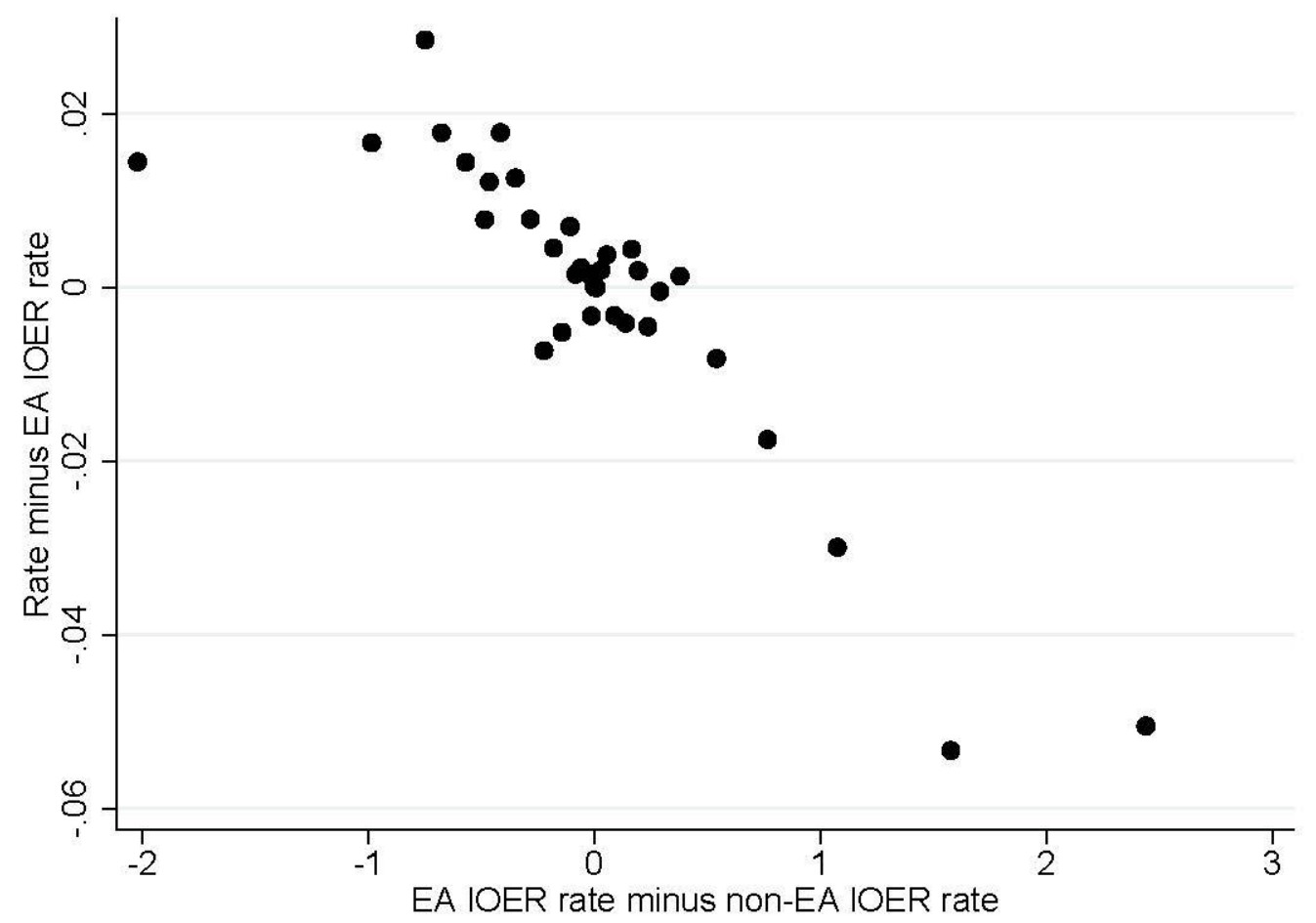

Notes: This figure presents a bin scatter plot of the interest rate spread of a given loan to the EA IOER rate (on the vertical axis) and the difference of the EA IOER rate and the IOER rate in the non-EA bank's home country IOER rate. The sample includes all loans by non-EA banks as lenders. Bank fixed effects are partialled out from both variables. 
TABLE A1 - DeFINITIONS OF VARIABLES

\begin{tabular}{|c|c|}
\hline Variable & Definition \\
\hline Rate $_{i, j, t}$ & $\begin{array}{l}\text { Interest rate (in percent) of overnight loan between lender bank } \mathrm{i} \text { and borrower } \\
\text { bank } \mathrm{j} \text { at day } \mathrm{t} \text {. }\end{array}$ \\
\hline Below IOER Rate $e_{i, j, t}(0 / 1)$ & $\begin{array}{l}\text { Dummy variable that equals the value of one if the overnight loan between lender } \\
\text { bank } i \text { and borrower bank } j \text { at day } t \text { is traded at a rate below the IOER rate of the } \\
\text { same day } t \text {, and zero otherwise. }\end{array}$ \\
\hline Dummy (Non-EA to EA) $)_{i, j}$ & $\begin{array}{l}\text { Dummy variable that equals the value of one if for any given bank pair the lender } \\
\text { bank is from a non-EA country and the borrower bank is from an EA country, } \\
\text { and zero otherwise. }\end{array}$ \\
\hline IOER rate $_{t}$ & $\begin{array}{l}\text { Interest rate (in percent) at which the ECB remunerates excess reserves held in } \\
\text { the IOER facility prevailing at day t. }\end{array}$ \\
\hline Corridor width $\mathrm{t}_{\mathrm{t}}$ & $\begin{array}{l}\text { Difference between the marginal lending facility (in percent) and the IOER rate } \\
\text { (in percent) of the ECB prevailing at time t. }\end{array}$ \\
\hline Lender's HHI $\mathrm{H}_{\mathrm{i}, \mathrm{t}}$ & $\begin{array}{l}\text { Equals the sum of the squared bank-pair lending shares of lender bank i with } \\
\text { respect to all other banks on day t, computed based on its lending activity during } \\
\text { the previous } 30 \text { days. }\end{array}$ \\
\hline Borrower's $\mathrm{HHI}_{\mathrm{j}, \mathrm{t}}$ & $\begin{array}{l}\text { Equals the sum of the squared bank-pair borrowing shares of borrower bank } \mathrm{j} \\
\text { with respect to all other banks on day t, computed based on its borrowing activity } \\
\text { during the previous } 30 \text { days. }\end{array}$ \\
\hline Open market operationst & $\begin{array}{l}\text { Logarithm of total amount (in EUR thousands) outstanding associated with open } \\
\text { market operations (main refinancing operations and longer-term refinancing op- } \\
\text { erations). }\end{array}$ \\
\hline FRFA dummyt & $\begin{array}{l}\text { Dummy that equals the value of one for all days after October } 15,2008 \text {, when } \\
\text { the Eurosystem introduced the fixed-rate, full-allotment policy, and zero other- } \\
\text { wise. }\end{array}$ \\
\hline Excess reservest & $\begin{array}{l}\text { Logarithm of total amount (in EUR thousands) of excess reserves held by all } \\
\text { banks at the IOER facility of the Eurosystem at day t. }\end{array}$ \\
\hline $\begin{array}{l}\text { Excess Reserves Held at } \\
\text { IOER Facilityj,t }\end{array}$ & $\begin{array}{l}\text { Logarithm of total excess reserves (in EUR million) held by individual bank i at } \\
\text { the IOER facility of the Eurosystem at day t. }\end{array}$ \\
\hline Fraction reserve holdingst & $\begin{array}{l}\text { Share of total excess reserves at the IOER facility of the Eurosystem held by bank } \\
\text { i at day t. }\end{array}$ \\
\hline Last day of $\mathrm{RMP}_{\mathrm{t}}$ & $\begin{array}{l}\text { Dummy that equals the value one if day } t \text { is the last day of a reserve maintenance } \\
\text { period. }\end{array}$ \\
\hline Money market liquidity & $\begin{array}{l}\text { Index that measures the liquidity in money markets; higher values indicate more } \\
\text { liquid markets; see Financial Stability Review, ECB, June } 2007 .\end{array}$ \\
\hline $\begin{array}{l}\text { General financial market } \\
\text { liquidityt }\end{array}$ & $\begin{array}{l}\text { Index that measures the liquidity in foreign exchange, bond, and equity markets; } \\
\text { higher values indicate more liquid markets; see Financial Stability Review, ECB, } \\
\text { June } 2007 \text {. }\end{array}$ \\
\hline
\end{tabular}


TABLE A2 - EFFECT OF IOER ON INTERBANK RATES DEPENDING ON OUTSIDE OPTIONS AND BARGAINING POWER

\begin{tabular}{|c|c|c|c|c|c|}
\hline & \multicolumn{5}{|c|}{ Dependent Variable: Rate - IOER } \\
\hline & $(1)$ & $(2)$ & (3) & $(4)$ & $(5)$ \\
\hline Corridor width & $\begin{array}{c}28.627 * * * \\
(0.21)\end{array}$ & $\begin{array}{c}35.129 * * * \\
(0.33)\end{array}$ & & & \\
\hline IOER rate & $\begin{array}{c}14.480 * * * \\
(0.05)\end{array}$ & $\begin{array}{c}13.945^{* * *} \\
(0.07)\end{array}$ & & & \\
\hline Dummy (Non-EA to EA) & $\begin{array}{c}-28.237 * * * \\
(0.71)\end{array}$ & $\begin{array}{c}-31.558 * * * \\
(1.10)\end{array}$ & & & \\
\hline Corridor width*Dummy (Non-EA to EA) & $\begin{array}{c}11.296 * * * \\
(0.46)\end{array}$ & $\begin{array}{c}11.345^{* * *} \\
(0.73)\end{array}$ & $\begin{array}{c}6.677 * * * \\
(0.38)\end{array}$ & $\begin{array}{c}6.188 * * * \\
(0.40)\end{array}$ & $\begin{array}{c}6.904 * * * \\
(0.40)\end{array}$ \\
\hline IOER rate*Dummy (Non-EA to EA) & $\begin{array}{c}-0.899 * * * \\
(0.11)\end{array}$ & $\begin{array}{c}0.471 * * * \\
(0.17)\end{array}$ & $\begin{array}{c}-1.099 * * * \\
(0.11)\end{array}$ & $\begin{array}{c}-2.703^{* * * *} \\
(0.13)\end{array}$ & $\begin{array}{c}-0.982 * * * \\
(0.12)\end{array}$ \\
\hline Lender's HHI & $\begin{array}{c}-9.075^{* * *} * \\
(0.39)\end{array}$ & $\begin{array}{c}37.742 * * * \\
(2.53)\end{array}$ & $\begin{array}{l}-0.334 \\
(1.40)\end{array}$ & $\begin{array}{l}0.191 \\
(1.52)\end{array}$ & $\begin{array}{r}-0.441 \\
(1.71)\end{array}$ \\
\hline Borrower's HHI & $\begin{array}{c}6.060 * * * \\
(0.39)\end{array}$ & $\begin{array}{c}41.610^{* * *} \\
(2.91)\end{array}$ & $\begin{array}{c}13.516^{* * * *} \\
(1.70)\end{array}$ & $\begin{array}{c}8.116^{* * * *} \\
(1.94)\end{array}$ & $\begin{array}{c}11.405^{* * * *} \\
(1.99)\end{array}$ \\
\hline Lender's HHI*Dummy (Non-EA to EA) & $\begin{array}{c}2.812 * * * \\
(0.61)\end{array}$ & $\begin{array}{c}-20.151 * * * * \\
(4.44)\end{array}$ & $\begin{array}{l}2.083 \\
(2.31)\end{array}$ & $\begin{array}{c}7.597 * * * \\
(2.56)\end{array}$ & $\begin{array}{l}-0.901 \\
(2.94)\end{array}$ \\
\hline Borrower's HHI*Dummy (Non-EA to EA) & $\begin{array}{c}-21.228 * * * \\
(0.76)\end{array}$ & $\begin{array}{c}51.943 * * * \\
(7.28)\end{array}$ & $\begin{array}{c}8.588 * * * \\
(3.10)\end{array}$ & $\begin{array}{c}16.993 * * * \\
(3.45)\end{array}$ & $\begin{array}{l}1.209 \\
(3.52)\end{array}$ \\
\hline Corridor width*Lender's HHI & & $\begin{array}{c}-32.650 * * * \\
(1.67)\end{array}$ & $\begin{array}{r}-1.330 \\
(0.93)\end{array}$ & $\begin{array}{r}-0.303 \\
(0.97)\end{array}$ & $\begin{array}{c}-0.724 \\
(1.12)\end{array}$ \\
\hline Corridor width*Borrower's HHI & & $\begin{array}{c}-27.839 * * * \\
(2.02)\end{array}$ & $\begin{array}{c}-12.505^{* * *} \\
(1.10)\end{array}$ & $\begin{array}{c}-9.000 * * * \\
(1.24)\end{array}$ & $\begin{array}{c}-10.665 * * * \\
(1.32)\end{array}$ \\
\hline IOER rate*Lender's HHI & & $\begin{array}{c}1.654 * * * \\
(0.42)\end{array}$ & $\begin{array}{c}2.441 * * * \\
(0.27)\end{array}$ & $\begin{array}{c}1.167 * * * \\
(0.33)\end{array}$ & $\begin{array}{c}0.648^{*} \\
(0.34)\end{array}$ \\
\hline IOER rate*Borrower's HHI & & $\begin{array}{c}3.248 * * * \\
(0.46)\end{array}$ & $\begin{array}{c}3.665^{* * * *} \\
(0.33)\end{array}$ & $\begin{array}{c}2.956^{* * * *} \\
(0.41)\end{array}$ & $\begin{array}{c}4.159 * * * \\
(0.38)\end{array}$ \\
\hline Corridor width*Lender's HHI*Dummy (Non-EA to EA) & & $\begin{array}{c}18.295^{* * *} \\
(2.90)\end{array}$ & $\begin{array}{l}-0.547 \\
(1.50)\end{array}$ & $\begin{array}{c}-3.278^{* *} \\
(1.56)\end{array}$ & $\begin{array}{l}1.806 \\
(1.93)\end{array}$ \\
\hline Corridor width*Borrower's HHI*Dummy (Non-EA to EA) & & $\begin{array}{c}-21.759 * * * * \\
(3.77)\end{array}$ & $\begin{array}{l}0.406 \\
(1.79)\end{array}$ & $\begin{array}{l}-0.469 \\
(1.90)\end{array}$ & $\begin{array}{c}3.457^{*} \\
(2.03)\end{array}$ \\
\hline IOER rate*Lender's HHI*Dummy (Non-EA to EA) & & $\begin{array}{c}-2.309 * * * \\
(0.76)\end{array}$ & $\begin{array}{c}-2.995 * * * \\
(0.47)\end{array}$ & $\begin{array}{c}-2.520 * * * \\
(0.57)\end{array}$ & $\begin{array}{c}-1.628 * * * \\
(0.61)\end{array}$ \\
\hline IOER rate*Borrower's HHI*Dummy (Non-EA to EA) & & $\begin{array}{c}-18.114 * * * \\
(1.47)\end{array}$ & $\begin{array}{c}-6.844 * * * \\
(0.62)\end{array}$ & $\begin{array}{c}-8.877 * * * \\
(0.77)\end{array}$ & $\begin{array}{c}-5.618^{* * *} * \\
(0.69)\end{array}$ \\
\hline RMP fixed effects & Yes & Yes & - & - & - \\
\hline Loan amount control & Yes & Yes & Yes & Yes & Yes \\
\hline Time fixed effects & No & No & Yes & Yes & Yes \\
\hline Bank-pair fixed effects & No & No & No & No & Yes \\
\hline Pair*Time-Trend Fixed Effects & No & No & No & Yes & No \\
\hline Relationship Controls & No & No & No & No & Yes \\
\hline Observations & 371,805 & 371,805 & 371,805 & 371,805 & 371,805 \\
\hline R-squared & 0.382 & 0.384 & 0.900 & 0.915 & 0.900 \\
\hline
\end{tabular}

Notes: This table extends the analysis presented in Table 2. The dependent variable is the spread between the bilaterally negotiated interest rate of the loan between lender $i$ and borrower $j$ at day $t$ and the IOER facility rate (IOER rate) on the same day (in basis points). Robust standard errors are presented in parentheses. The definitions of all variables can be found in Table A1. 